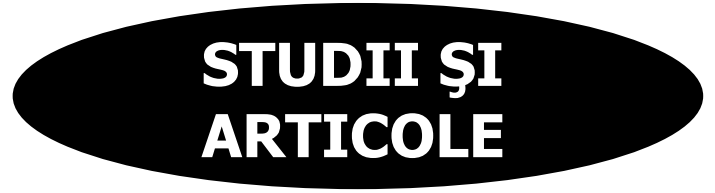

\title{
Pomenirile celor adormiți în cadrul Liturghiei Euharistice. Text și context
}

\section{Petru PRUTEANU*}

Abstract: The commemoration of the deceased in the Eucharist. Text and Context. The Byzantine Liturgy has several moments for the commemoration of the dead but, paradoxically, those meant to be made in the hearing of all are considered secondary, whilst those made in silance - during the Prothesis and the Anaphora (even if in some periods the Anaphora was recited aloud) - are understood of primary importance. It is a fact that the nominal commemorations made in the received tradition during the Prothesis (Proskomide) are originated inclusively from the transition of the deaconal dipthychs of the Anaphora where only some remnants of the ancient diptychs and intercessions of the priest are still present. These unheard and ignored intercessions (even because of the singing of the Axion), were in the past the core of the ancient prayers for the living and the dead. In this paper, the author selects and analyzes the primary eucharistic texts referring to this matter, discussing the context in which each local liturgical tradition understood and practiced the eucharistic prayer for the deceased.

Keywords: Anaphora, commemorations, defuncts, diptychs, Eucharistic prayer, intercession, Prothesis.

\section{Introducere}

Pomenirea generală şi/sau nominală a celor adormiți în cadrul cultului liturgic reprezintă o tradiție creștină genuină. În

\footnotetext{
* Doctor în Teologie al Academiei Duhovniceşti din Kiev; profesor de Liturgică la Centrul Ortodox de Studii şi Cercetare „Dumitru Stăniloae” din Paris.
} 
primele două-trei secole aceste pomeniri erau legate, de obicei, de comemorările anuale ale unor martiri sau personalități bisericeşti, dar foarte curând au devenit o practică comună pentru toţi creştinii „adormiţi întru dreapta credinţă” şi ,,întru nădejdea învierii şi a vieţii veşnice". Aceste pomeniri erau făcute atât la înmormântarea creştinilor, cât şi la diferite perioade după aceasta: 7/9 zile², 30/40 de zile ${ }^{3}$, iar apoi în fiecare an la dies natalis ${ }^{4}$. Abia după libertatea

${ }^{1}$ Este important să subliniem că rugăciunile Bisericii pentru cei adormiţi au fost condiţionate tot timpul de această credinţă şi nădejde, iar formulele de mai sus au devenit clasice pentru cultul bizantin (vezi Elena VeLKovsKA, „Funeral Rites According to the Byzantine Liturgical Sources”, în Dumbarton Oaks Papers, 55/2001, pp. 21-51). Spre sfârşitul sec. IV, Constituţiile Apostolice (cartea VIII, §XLIII - „Că necredincioşilor care au murit nu le folosesc la nimic pomenirile”) atenţionează: „Acestea [adică cele despre pomeniri din §XLI-XLII; n.n.] le spunem însă despre cei dreptcredincioşi; căci pentru necredincios, chiar de ai da săracilor cele ale lumii, nu-i va fi de nici un folos. Pentru că dacă pe când era în viaţă L-a avut duşman pe Dumnezeu, este evident că-L va avea tot aşa şi după ce s-a mutat de aici, «căci nu este nedreptate la El» [In. 7, 18]. «Căci drept este Domnul şi a iubit dreptatea» [Ps. 10, 7]. Şi: «Iată omul şi lucrul său» [Is. 62, 11]" (cf. CO1, p. 766). Aceasta nu înseamnă o lipsă de nădejde pentru mântuirea celor păcătoşi (pentru care ne putem ruga în afara Liturghiei), şi nici nu contrazice întâmplarea din Viaţa Sf. Macarie Egipteanul, care a vorbit cu sufletul unui păgân despre mângâierea (nu mântuirea!) ce o au cei din iad ca urmare a rugăciunilor creștinilor (cf. SFÎntul MACARIE EgIPTEAnul, Scrieri. Omilii duhovnicești, trad. Constantin Cornițescu, introd. N. Chițescu, col. „Părinți și scriitori bisericești”, 34, București, Edit. Institutului Biblic și de Misiune al Bisericii Ortodoxe Române, 1992, p. 65).

${ }^{2}$ Spre sfârşitul sec. IV Sinesiu de Cirene ne dă mărturie despre tradiţia occidentală când în a 7-a zi (nu în a 9-a, cum prevăd în aceeaşi perioadă Constituţiile Apostolice în Răsărit), să se facă pomenire pentru cel adormit şi să se ofere o masă pentru nevoiași (cf. Epistola III, apud AL, §2704, p. 768). Până astăzi romano-catolicii fac pomenire la 3,7 şi 30 de zile.

${ }^{3}$ Despre pomenirea în a 30-a zi (nu a 40-a) scrie şi Sf. Efrem Sirul în Testamentul său: ,Veniţi, fraţii mei, întăriţi-mă, căci a slăbit foarte duhul meu. Purtaţi-mă în psalmi și în rugăciunile voastre, [și] încredinţaţi-mă că veţi aduce jertfe după obicei și pentru slăbiciunea mea. Și când se [va împlini] a treizecea [zi], săvârşiţi pomenirea mea, căci cei morţi se folosesc prin jertfele de pomenire aduse de sfinţii cei vii" (Beati Ephraem Testamentum, 413,13-415,11, apud Eustratie Din CONSTANTINOPOL, Despre starea sufletelor după moarte, Iași, Edit. Doxologia, 2019, pp. 198-200). 
dată creştinilor în anul 313, cultul martirilor şi rânduielile funerare ale creştinilor au început să se dezvolte în mod liber, iar ziua specifică pentru pomenirea săptămânală a martirilor şi a celor adormiți a devenit sâmbăta 5 .

Deja prin sec. VIII-IX, existau câteva sâmbete speciale dedicate pomenirii morţilor ( $\tau \grave{\alpha} \psi v 0 \chi \sigma \alpha \dot{\alpha} \beta \beta \alpha \tau \alpha$ ), iar două dintre acestea - Sâmbetele dinaintea Duminicii Lăsatului sec de Carne şi a Cincizecimii ${ }^{6}$, numite generic ,ale tuturor părinţilor şi fraţilor de la începutul veacurilor: de la Adam până astăzi" "7. - sunt considerate cele mai importante. Lor se adaugă şi sâmbetele a doua, a treia şi a patra din Postul Mare, „Paştele blajinilor”, „Ziua eroilor” şi „Sâmbăta Sf. Dimitrie", dar toate acestea, spre deosebire de cele două sâmbete amintite mai sus, nu au slujbe dedicate exclusiv morţilor, ci, conform Tipicului, pomenirea celor adormiţi se adaugă ca element secundar slujbei principale a zilei (din Triod, Penticostar sau Minei) ${ }^{8}$.

Prin sec. IV-V pomenirile celor adormiți încă aveau forme spontane şi improvizate, legate într-o formă sau alta de Liturghia euharistică (care implică slujirea sacerdotală), dar se dezvoltau şi în cadrul altor slujbe zilnice. $\mathrm{Cu}$ timpul, comemorările „extraeuharistice" au căpătat locuri stabile în Ceaslov: la sfârşitul

${ }^{4}$ În Constitutiile Apostolice (VIII, XLII) se spune: „Să se celebreze cea de-a treia zi a celor adormiţi în psalmi şi rugăciuni din pricina Celui ce S-a sculat a treia zi, a noua zi spre aducerea-aminte a celor ce au rămas şi a celor adormiţi, a treizecea zi după exemplul vechi, căci aşa l-a jelit pe Moise poporul $(D t .34,8)$ şi împlinirea unui an spre pomenirea lui. Şi să se dea din averile lui săracilor în amintirea lui." (apud CO1, p. 766).

${ }^{5}$ Părintele Macarie Simonopetritul, făcând apel la tradiţia patristică, leagă acest lucru de teologia Sâmbetei celei Mari, când Hristos a coborât la iad pentru a vesti celor adormiți învierea şi mântuirea; $T E X$, p. 297. Până astăzi, fiecare zi de sâmbătă are în Octoih stihiri şi tropare (la Canonul Utreniei) pentru cei adormiţi, dar acestea nu sunt elementele principale ale slujbei de sâmbătă şi se pun doar atunci când nu este perioada unui Praznic, iar slujba din Minei are un singur Canon la Utrenie.

${ }^{6}$ SAHAROV, cap. II, p. 29. Vezi şi Miguel ARRANZ, „Les prières de la Gonyklisia ou de la Génuflexion du jour de la Pentecôte dans l'ancien Euchologe byzantine", în $O C P, 48 / 1982$, pp. 92-123.

${ }^{7}$ TEX, pp. 297-300. Vezi şi nota 50 de la p. 498.

${ }^{8}$ SAHAROV, cap. II, pp. 31-32. 
Miezonopticii (de luni până sâmbătă, nu şi duminica) - printr-un oficiu mai extins, dar şi în cadrul Pavecerniţei şi al Obedniţei - prin condacul „Cu sfinţii odihneşte, Hristoase...”".

$\mathrm{Cu}$ toate acestea, cadrul prin excelenţă de pomenire a celor adormiţi rămâne Liturghia euharistică, chiar dacă locul şi forma acestor pomeniri a suferit mai multe schimbări de-a lungul timpului $^{10}$. În rânduiala actuală a Liturghiei bizantine ${ }^{11}$ există următoarele momente în care trebuie sau putem pomeni pe cei adormiţi (nominal sau general): prothesis $^{12}$;

a) pomenirile generale şi nominale la proscomidie/

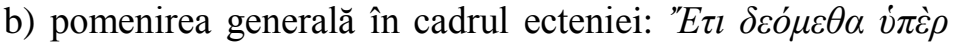

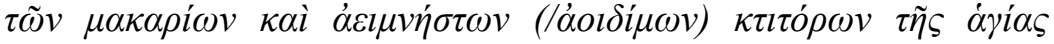

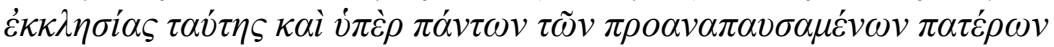
$\kappa \alpha i \quad \dot{\alpha} \delta \varepsilon \lambda \varphi \tilde{\omega} v \quad \dot{\eta} \mu \tilde{\omega} v, \quad \tau \tilde{\omega} v \quad \dot{\varepsilon} v \theta \dot{\alpha} \delta \varepsilon \quad[\varepsilon \dot{v} \sigma \varepsilon \beta \tilde{\omega} \varsigma]^{13} \quad \kappa \varepsilon \tau \mu \varepsilon \dot{v} v \omega v \quad \kappa \alpha i$

${ }^{9}$ Ibidem, p. 42.

${ }^{10}$ Singurele studii care ating acest subiect, dar fără a analiza textele liturgice din diferite tradiţii locale, sunt: Vasileios MARINIS, Death and the Afterlife in Byzantium: The Fate of the Soul in Theology, Liturgy, and Art, New York, Cambridge University Press, 2017, în special cap. VII, pp. 93-106; şi Cyril KEnNEDY, „The Divine Liturgy and the Byzantine Funeral: History and Contemporary Practice", în Liturgy, 33.1/2017, pp. 26-33. Câteva aspecte privind vechile liturghii occidentale la: Joseph NTEDIKA, L'évocation de l'au-delà dans la prière pour les morts. Étude de patristique et de liturgie latines (IVe-VIIIe s.), Louvain-Paris, Publications de l'université de Lovanium Kinshasa 1971, pp. 88-103.

11 În varianta greacă a IAC, pe lângă pomenirile-mijlociri din anafora, există şi alte trei pomeniri ale celor adormiţi: în rugăciunea-binecuvântare de după Intrarea Mică, în rugăciunea de după Intrarea Mare şi în Ectenia Mare de dinainte de anafora. Întrucât primele două momente lipsesc din versiunea siriacă şi georgiană a formularului, se consideră că acestea ar fi interpolări târzii, iar singurul loc extra-anaforal de pomenire al celor adormiţi ar fi Ectenia Mare.

12 Pentru corectitudine vom numi ritualul de pregătire al darurilor euharistice: „prothesis” şi nu „proscomidie” întrucât acest al doilea termen (folosit de slavi şi români pentru prothesis) poate însemna şi ,punerea-înainte” a Darurilor (după Intrarea Mare), dar şi anaforaua euharistică sau chiar întreaga Liturghie (vezi Михаил ЖЕлтов „Проскомидия”, în Православная Энциклопедия, vol. 58, p. 419). Problema pomenirilor la prothesis va fi dezvoltată în ultimul capitol al acestui studiu.

${ }^{13}$ Cuvântul din paranteză a fost adăugat în mss. şi tipărituri începând cu sec. XVI, neîntâlnindu-se anterior; $\Sigma \Sigma \Theta \Lambda$, pp. 129-130. 
$\dot{\alpha} \pi \alpha v \tau \alpha \chi o \tilde{v} \dot{o} \rho \theta \delta \delta \dot{\xi} \xi \omega v / /$ Traducerea românească un pic diferită: „Încă ne rugăm pentru fericiții și pururea pomeniții ctitori ai sfânt locașului acestuia și pentru toți cei mai dinainte adormiți părinți și frați ai noștri ortodocşi [creștini], care odihnesc aici şi pretutindeni" 14 .

c) după ectenia obișnuită, o ectenie specială pentru adormiţi cu rugăciunea „Dumnezeul duhurilor..." ${ }^{15}$, care se regăseşte doar în Liturghierele slavo-ruse (începând cu sec. XV) ${ }^{16}$ şi în cele româneşti (începând cu sfârşitul sec. XVII-XVIII) ${ }^{17}$;

d) pomenirile de la Intrarea Mare, care încep să se dezvolte

${ }^{14}$ Această cerere se întâlneşte identic şi în rânduiala Vecerniei şi a Utreniei şi, de obicei, apare pe la mijlocul ecteniei, după cererile pentru clerici. Se pare că această poziționare a cererii se datorează faptului că cei mai mulţi „,ctitori” pomeniţi erau din familiile regale sau senatoriale, iar Biserica, având structură ierarhică, îi pomenea pe ctitori (de regulă, aparținători ai înaltei clase sociale) în fruntea tuturor laicilor (fără să se ţină seama de faptul că unii sunt deja morţi, iar alţii încă vii). Logic însă, această cerere ar trebui să încheie ectenia (aşa cum avem în mod corect la sfârş̧itul Miezonopticii sau Pavecerniţei Mari), idee pe care am şi implementat-o în $L M$, pp. 14, 78 .

15 Pentru câteva studii despre această veche rugăciune a se vedea Nicolae PREDA Nicolae PREDA, ,The prayer «God of the spirits» a brief historical and liturgical analysis”, în Ephemerides Liturgiae, 132/2018, p. 220-232; „The prayer "God of the spirits» - short textual analysis”, în Icoana Credinței, 4/2018, p. 48-62; „The prayer «God of the spirits» (an expression that disappeared from liturgical structures: «in Abraham's, Isaac's and Jacob's bosoms»)", în International Journal of Theology, Philosophy and Science, 1/2017, p. 36-44.

16 Iniţial această ectenie apărea cu indicaţia de a înlocui în zilele de sâmbătă ectenia obişnuită, iar mai târziu s-a adăugat acesteia, dar tot numai pentru zilele de sâmbătă. Detalii: Михаил ЖЕЛтов, „Чин Божественной Литургии в древнейших (XI-XIV вв.) славянских рукописей”, în Богословские mpyдbl, 41/2007, p. 278.

17 Primele traduceri româneşti (Dosoftei - Iaşi, 1679 şi Antim Ivireanul Târgovişte, 1706/1713) încă nu conţin această ectenie pentru cei adormiţi în cadrul Liturghiei. Ectenia nu se întâlneşte nici în ms. slavon de la Suceviţa (anul 1607), ceea ce arată că nici Liturghierele slavoneşti nu o conţineau cu regularitate. Prima apariţie a ecteniei în spaţiul românesc este în Liturghierul slavo-român de la Bucureşti (a. 1680) cu precizarea condiţională „,De va fi Prinos sau Liturghie pentru cei morţi” (f. $31^{\mathrm{v}}$ ), apoi, cu aceeaşi menţiune, în Rânduiala Diaconstvelor de la Bălgrad (a. 1687) (f. $5^{\mathrm{r}}$ ). Deja în Liturghierele de la Iaşi (a. 1759) (f. 54 ${ }^{\mathrm{r}}$ ) şi Râmnic (a. 1767) (f. 56²) apare menţiunea „Iar când va fí pomenirea pentru cei morţi”. 
începând cu sec. XII-XIII. Iniţial acestea erau doar pentru cei vii, iar cele pentru adormiţi, deşi se mai practică în forme improvizate şi la greci (ca o singură cerere), sunt fixate oficial doar în Liturghierul românesc (cu patru-cinci cereri) ${ }^{18}$, nefiind întâlnite la ruşi ${ }^{19}$;

e) cererea de mijlocire (intercessio) de după epicleză, precedată sau succedată de dipticele diaconale;

f) pomenirile la binecuvântarea colivei pentru cei adormiţi (încadrată sau nu în rânduiala Trisaghionului/Litiei pentru cei adormiţi $)^{20}$, ce se face după „Rugăciunea din spatele amvonului”.

Analizând vechile izvoare liturgice, observăm că cele mai vechi şi mai importante pomeniri, atât pentru adormiţi, cât şi pentru vii, erau cele din cadrul anaforalei, adică mijlocirile preotului şi dipticele diaconale, iar toate celelalte pomeniri din cadrul Liturghiei sunt mult mai noi, unele dintre ele ( $c, d$ şi $f$ ) rămânând până astăzi simple tradiţii locale sau comemorări opţionale. Prin urmare, studiul nostru se va limita la vechile pomeniri generale şi nominale din cadrul anaforalei (sec. IV-XII), după care vom analiza şi migrația acestor pomeniri spre prothesis, precum şi dezvoltarea rânduielii şi a interpretărilor legate de acest rit (sec. XI-XIV).

\section{Importanţa pomenirii celor adormiţi la Liturghia euharistică}

Practica liturgică a pomenirii celor adormiţi la Liturghie este consemnată şi confirmată de numeroase mărturii patristice din Răsărit şi Apus în care, nu doar se menționează faptul istoric al pomenirilor, ci se aduc şi argumente teologice privind folosul şi necesitatea acestora. Printre părinţii care fac referiri directe sau indirecte la rugăciunea

\footnotetext{
${ }^{18}$ Liturghier, pp. 163-164.

${ }^{19}$ Detalii: LOIA, pp. 116-117.

20 Despre istoria şi structura acestei rânduieli a se vedea la Nicolae PREDA, „Trisaghionul pentru cei morţi (analiză istorico-liturgică)”, în Biserica Ortodoxă Română, 1/2015, pp. 238-257; „«Litia mică pentru cei morţi» rânduială (un alt formular «inedit» al Abaţiei din Grottaferrata)", în Ortodoxia 2/2019, pp. 82-91; , «Litia mică pentru cei morţi» (rânduială de tip palestinian)”, în Ortodoxia 3/2019, pp. 93-111.
} 
euharistică pentru cei adormiţi enumerăm în special pe Ignatie Teoforul, Ciprian al Cartaginei, Serapion de Thmuis, Efrem Sirul, Chiril al Ierusalimului, Epifanie de Salamina, Ioan Hrisostom ${ }^{21}$, Teodor de Mopsuestia, Sinesiu de Cirene, Papa Inocenţiu I, Fericitul Ieronim, Fericitul Augustin, Pseudo-Dionisie Areopagitul, Grigorie de Tours, Iacov de Sarug, Balai Horepiscopul, Narsai, Gavriil de Basra, Eustratie din Constantinopol ${ }^{22}$, Grigore Dialogul, Anastasie Sinaitul ş.a. ${ }^{23}$ Pentru a înţelege cugetul Bisericii primare cu privire la sensul şi importanţa pomenirii celor adormiţi în cadrul anaforalei şi, în special, în faţa jertfei euharistice ${ }^{24}$, vom reda două dintre cele mai relevante texte patristice la acest subiect.

a) Cateheza a V-a Mistagogică a Sf. Chiril al Ierusalimului (§ 8-10):

„După săvârşirea jertfei duhovnicești, slujba cea fără de sânge, rugăm, asupra acestei jertfe de ispășire, pe Dumnezeu: pentru pacea de obște a Bisericilor, pentru buna rânduială a lumii, pentru conducători, pentru ostași și cei care ne ajută în lupte, pentru cei bolnavi, pentru cei care se trudesc, şi, în general, ne rugăm și aducem această jertfă pentru toți care au nevoie de ajutor. Apoi facem pomenire și de cei mai înainte adormiți, mai întâi de patriarhi, de profeți, de apostoli, de mucenici, pentru ca Dumnezeu, prin rugăciunile și mijlocirile lor, să primească cererea noastră; apoi ne rugăm și pentru cei mai înainte adormiți sfinţi părinţi şi episcopi şi, scurt vorbind, pentru toți cei adormiți înainte de noi. Credem că vor dobândi

${ }^{21}$ A se vedea mai ales Omilia 41 la Epistola I către Corinteni (PG 61, 355-361).

22 Acest preot al Catedralei Aghia Sofia, a fost secretarul patriarhului Eutihie al Constantinopolului (553-565, 577-582) şi a scris un tratat intitulat Despre starea sufletelor după moarte (trad. rom. Ierom. Arsenie Pohrib, Iași, Edit. Doxologia, 2019), în care combate părerea unor teologi sirieni despre starea de amorţire şi inconştienţă a sufletelor după moarte. În primele două părţi ale tratatului el arată că sufletele sunt conştiente şi după moarte, şi anume aşa se explică arătările şi rugăciunile sfinţilor pentru noi, iar în partea a treia, citând pe Dionisie Areopagitul, Efrem Sirul, Chiril al Ierusalimului, Chiril al Alexandriei şi pe Ioan Gură de Aur, autorul justifică şi rugăciunile pentru cei adormiţi.

23 Textele extinse ale acestor autori se pot vedea în $A L$, pp. 560-1547, iar citatele legate strict de mijlociri sau diptice se găsesc şi în Dipticele, pp. 27-48.

24 Aspect subliniat de papa Inocenţiu I, dar fără consecinţe majore în practica apuseană; vezi Dipticele, pp. 23-24. 
cel mai mare folos sufletele pentru care facem rugăciune la jertfa sfântă și prea înfricoșătoare ce este pusă înainte..."25.

b) Omilia lui Iacov de Sarug (†521) - „Despre pomenirea morţilor şi despre Pâinea Euharistică şi despre faptul că morţii au folos în urma darurilor şi a milosteniei date pentru ei” (§ 1-14):

„Adu pâine și vin și iubire la locul de împăcare, încât preotul să vină înaintea Măreției cu pomenirile tale. Pe pietrele efodului Moise scrisese numele semințiilor, ca preotul să poată duce înăuntrul Sfintei sfintelor pomenirea lor. Iar tu, alături de pâinea euharistică înscrie pomenirile tale și ale celor mutați, și dă-o preotului să o aducă înaintea lui Dumnezeu [...] Dă-i lui Dumnezeu numele său și pomenirea ta alături de jertfa ta [...] Aici [în biserică] sunt puse înainte pomenirile lor și numele lor în marea carte a Dumnezeirii, în care toți sunt... / Pentru sufletele celor morți, preotul intră și pune pe masă pâinea și vinul tainelor; şi pomenește acolo moartea lui lisus și, asemenea, învierea Sa. Și pe fiecare din cei mutați îi pomenește la jertfă pentru a fi iertați; și pe toți cei ce au oferit și au adus pâinea euharistică, cu iubire îi pomenește. Și, pentru o aducere aminte a mutării lor, el însemnează Taina; şi pentru toți cei morţi care au adormit el aduce jertfele. Îl cheamă pe Tatăl şi Îi amintește de moartea Fiului Său; iar Duhul este trimis și coboară și odihnește asupra jertfei... / La fel și urmașii celui mort aduc pâine și vin în numele lui, la altar; și rugăciunea preotului și a poporului se face pentru cel mutat; iar Domnul îl iartă pe cel mort a cărui pomenire ei o săvârșesc [...] Credința Bisericii aceasta este, bunilor prieteni, și aceasta [Biserica] poate face ca pâinea și vinul să devină Trupul și Sângele. [Biserica] frânge pâinea, dar știe că nu [este] pâine, ci Trupul; și amestecă vinul, dar afirmă că în vasele sale este Sânge. Şi [Biserica] citește numele tuturor celor morți ai săi deasupra jertfei, și pe aceștia îi adună cu dânsa în jertfele duhovnicești”26.

25 Sf. Chiril al Ierusalimului, Cateheze, București, Edit. Institutlui Biblic şi de Misiune al Bisericii Ortodoxe Române, 2003, pp. 361-362.

${ }^{26}$ Un scurt citat în Dipticele, pp. 43-44 (cu unele corectări stilistice). Vezi textul integral al Omiliei în $A L$, pp. 1358-1361. 
La aceste idei patristice se adaugă şi tematica eshatologică trăită şi exprimată pregnant în anaforale şi menţionată în anamneza euharistică prin comemorarea anticipativă a „slăvitei şi a doua veniri" a Domnului şi a Împărăției care vine ${ }^{27}$.

După cum spunea pe la sfârşitul sec. al II-lea Sf. Irineu al Lyonului: „credinţa noastră este conformă cu Euharistia, iar Euharistia confirmă credinţa" (Adv. Haer. IV, 18, 5). Acest principiu a fost dezvoltat mai târziu de ucenicul lui Augustin, Prosper de Aquitania ( $† 455)$, care spunea: „Legem credendi lex statuat supplicandi" (simplificat mai târziu la expresia , lex orandi [est] lex credendi"). Prin urmare, cultul şi doctrina se exprimă şi se conţin reciproc, de aceea, este interesant să vedem cum credinţa creştină privind folosul rugăciunilor şi aducerii jertfei euharistice pentru cei adormiţi erau exprimate în cult, mai ales că tradiţiile liturgice locale erau atât de diverse.

Fiind ajutaţi de cercetările fundamentale ale Gabrielei Winkler $^{28}$ şi ale lui Robert Taft $^{29}$ referitoare la rugăciunile de mijlocire şi diptice, observăm că:

1) Practica pomenirii celor adormiţi în cadrul euharistiei este la fel de veche ca şi euharistia însăși ${ }^{30}$. În anaforalele creştine aceste

27 PARENTI, p. 416. Cred că este important să menționăm că primele rânduieli de înmormântare începeau cu ecfonisul „Binecuvântată este Împărăţia...” (Christodoulos, pp. 86-87), chiar dacă, aşa cum explică G. Passarelli, acest ecfonis era unul comun pentru toate slujbele constantinopolitane, inclusiv pentru Vecernie, Utrenie şi chiar pentru unele ierurgii neînsemnate, fără sensul eshatologic pe care-1 oferim noi astăzi, când doar rânduielile Sfintelor Taine încep astfel (cf. Gaetano PASSARELLI, „La Benedizione iniziale dell’Enarxis nella Liturgia bizantina”, Bollettino di Grottaferrata, 28/1974, pp. 32-34.

28 Gabriela WINKLER, „Die Interzessionen der Chrysostomusanaphora in ihrer geschichtlichen Entwicklung", în $O C P, 36 / 1970$, pp. 301-336 şi partea a doua în $O C P, 37 / 1971$, pp. 333-383.

${ }^{29}$ Robert F. TAFT, O istorie a Liturghiei Sfântului Ioan Gura de Aur, vol. IV: Dipticele, trad. Cezar Login, Cluj-Napoca, Edit. Renaşterea, 2009.

${ }^{30}$ Unii liturgişti precum L. Bouyer, L. Ligier sau M. Arranz consideră că inclusiv rădăcina acestor pomeniri ar trebui căutată în vechile rugăciuni iudaice. În cultul iudaic actual rugăciuni generale pentru adormiţi se fac de patru ori pe an şi se numesc Yizkor sau Hazkarat Neshamot, dar rădăcinile acestora pot fi urmărite până în epoca Macabeilor. Vezi şi $P E$, pp. 5-60. 
pomeniri apar sub două forme: ca rugăciuni generale de mijlocire rostite de protos (episcop sau preot) sau ca pomeniri nominale (de pe diptice), săvârşite de obicei de către diaconi.

2) Absenţa unor cereri de mijlocire din unele formulare euharistice cum ar fi Tradiţia Apostolică, atribuită lui Ipolit al Romei $\left(\text { sec. III) }{ }^{31} \text { şi Anaforaua de pe Papirusul de la Barcelona (sec. IV) }\right)^{32}$, nu înseamnă, în mod automat, lipsa oricăror pomeniri în cadrul general al acelor Liturghii. De exemplu, în Cilicia, Mesopotamia, precum şi în riturile galican şi spaniol, aceste pomeniri nu făceau parte din rugăciunea euharistică, ci erau legate mai degrabă de ofertoriul preanaforal sau de transferul darurilor, când erau pomeniţi „cei ce au adus şi cei pentru care s-au adus" 33 .

3) Majoritatea absolută a anaforalelor din Răsărit şi Apus (inclusiv unele fragmente de anaforale cum ar fi cel de pe Papirusul de la Strasbourg $^{34}$ ) conţin cel puţin rugăciuni generale de mijlocire pentru cei adormiţi. In funcţie de tradiţia locului şi perioada de dezvoltare a fiecărui formular liturgic, aceste mijlociri sacerdotale (urmate/precedate sau nu de dipticele diaconale) se pot întâlni în momente şi forme diferite:

a) după Prefatio şi înainte de Sanctus - în tradiţia alexandrină: Liturghia Sf. Marcu, cea coptă a Sf. Chiril al Alexandriei ${ }^{35}$, dar şi în descrierea lui Pseudo-Dionisie Areopagitul (cf. Despre ierarhia bisericească, cap. III, 9 şi cap. VII);

${ }^{31}$ LOIA, pp. 29-32.

${ }^{32}$ LOIA, pp. 38-39, 311-314.

33 Dipticele, pp. 19-20. Această expresie, cu posibile origini în Didascalia (sec. III), se regăsește şi în rugăciunea care încheie proscomidia bizantină atât pentru VAS, cât şi pentru CHR, chiar dacă în sec. VIII-IX cele două liturghii aveau rugăciuni diferite pentru prothesis (vezi М. ЖЕЛТОВ „Проскомидия”, p. 420). Este remarcabil faptul că în IAC, aceeași rugăciune se citeşte abia după Intrarea Mare, anume ca rugăciune a punerii-înainte ( $\tau$ c $\pi \rho o \sigma \kappa o \mu l \delta \eta^{\prime} \varsigma$ ) şi nu a prothesis-ului (MERCIER, p. 180).

34 JOHNSON, p. 255-259.

35 În IAC pomenirile sunt dezvoltate după epicleză, dar se regăsesc şi în introducerea la Sanctus, unde ,sufletele drepţilor şi ale prorocilor, sufletele martirilor şi ale apostolilor" participă alături de cetele îngereşti la cântarea întreit-sfântă $(P E$, p. 244247). O astfel de menţiune lipseşte în varianta siriacă a IAC; vezi: Baby VARGHESE, The Syriac Version of the Liturgy of St. James. A brief history for Students, col. „Gorgias Liturgical Studies”, 47, Gorgias Press, 2009, p. 24. 
b) după epiclezăa, ca o dezvoltare a acesteia - în toate anaforalele răsăritene, cu excepția principalelor anaforale alexandrine ${ }^{36}$ și a celor care nu au deloc intercessio;

c) după pomenirea celor vii - tradiţie specifică Liturghiei Sf. Iacov şi altor liturghii din Răsărit şi Apus;

d) înainte de pomenirea celor vii - particularitate a Liturghiilor constantinopolitane ale Sf. Vasile cel Mare şi a Sf. Ioan Hrisostom, dar cu posibile rădăcini siriene;

4) Într-o primă etapă (sec. IV-V) cererile de mijlocire pentru adormiţi erau inserate printre cele pentru vii sau apăreau nediferenţiate printre cererile pentru sfinţi, derivând din acestea ${ }^{37}$. Ştim, de asemenea, că aceste pomeniri erau şi sunt până astăzi însoțite de o tămâiere în fața Sfintei Mese, care are nu doar rolul de a cinsti darurile euharistie după consacrare, ci şi de a exprima simultan rugăciunea Bisericii pentru sfinţ̧i ${ }^{38}$ şi cea a sfinţilor pentru Biserică (cf. Apoc 8, 3-4). Se pare că anume la această tămâiere se referă şi horepiscopul sirian Balai (†432), când vorbeşte despre „beneficiile morţilor din privegheri, Euharistie şi cădire, atunci când preotul pomeneşte numele lor înaintea jertfelnicului" ${ }^{39}$.

${ }^{36}$ De exemplu Liturghia lui Serapion de Thmuis şi versiunea egipteană a VAS au aceste mijlociri după epicleză.

${ }^{37}$ Cele mai evidente exemple: Liturghia din Constituţiile Apostolice (VIII, 12), cea din Testamentum Domini şi „Liturghia celor 12 apostoli” - adică Liturghii care nu s-au mai slujit după sec. V şi nici înainte de aceasta nu aveau o răspândire foarte largă. Este vorba despre etapa primară de intercessio, care cu timpul a evoluat destul de mult.

38 Despre textul şi contextul acestor rugăciuni pentru sfinţi vezi: Robert TAFT, „Praying to or for the Saints? A Note on the Sanctoral Intercessions / Commemorations in the Anaphora", în M. SchneIDER, W. BERSCHIN, $A b$ Oriente et Occidente (Mt 8,11): Kirche aus Ost und West, Sankt-Ottilien, EOSVerlag, 1996, pp. 439-455; LOIA, pp. 166-171.

${ }^{39}$ Dipticele, nota 40, p. 8. Prin urmare, tămâierea făcută de preot în faţa Sfintei Mese trebuie să continue până se încheie mijlocirea generală pentru cei adormiţi şi abia apoi poate fi continuată de diacon în jurul Sfintei Mese. Acest lucru este prevăzut şi de noul Liturghier Vatopedin, care reglementează tămâierea până la terminarea dipticelor pentru adormiţi ( $\mu \dot{\varepsilon} \chi \rho \imath \tau \tilde{\eta} \varsigma$ $\sigma v \mu \pi \lambda \eta \rho \omega ́ \sigma \varepsilon \omega \varsigma \tau \tilde{\omega} v \delta \imath \pi \tau \dot{\chi} \chi \omega v \quad \tau \tilde{\omega} v \quad \tau \varepsilon \theta v \varepsilon \omega \dot{\tau} \omega v)$, cu precizarea că în acest 
5) Cel puţin până la sfârşitul sec. IV toate aceste mijlociripomeniri erau începute de preot, ca o prelungire a epiclezei, apoi erau continuate de către diacon. Deja spre sfârşitul secolului al V-lea cele două „repertorii”, sacerdotal şi diaconal, au căpătat forme şi sensuri diferențiate, mijlocirile generale fiind rezervate preotului, iar dipticele - diaconului. Uneori, izvoarele liturgice vorbesc şi despre alte înşirări de nume - un fel de pomelnic curent al comunității sau al celor prezenţi la acea slujbă: $\kappa \alpha \tau \alpha ́ \lambda o \gamma o \varsigma$ - citit de diaconi în taină, dar care nu trebuie confundat cu dipticele oficiale, rostite de către arhidiacon de pe amvon.

6) În perioada de maximă evoluţie a dipticelor diaconale (sec. V-IX), acestea constituiau o listă oficială de nume ale persoanelor cu care Biserica locală respectivă era în comuniune dogmatică şi euharistică ${ }^{40}$. Aceste diptice, pentru vii şi adormiţi, erau citite cu voce tare ${ }^{41}$, iar lista celor adormiţi cuprindea în mod obligatoriu succesiunea apostolică şi tradiţia istorică a acelei Biserici locale: începând cu (Maica Domnului - după Sinodul III Ecumenic,) apostolii locali, cei mai importanţi martiri şi ierarhi „ecumenici” şi locali, „împăraţii fondatori” ai Imperiului creştin şi alte personalități din acea regiune. Prin urmare, cererea diaconului de după anafora: „Pe toţi sfinţii pomenindu-i...”, îi are în vedere atât pe sfinţii ,canonizaţi”, cât şi pe toţi ceilalţi care făceau parte din acele diptice şi pomelnice: vii şi adormiţi. În prezent, dipticele pentru adormiţi, în forma lor primară, au dispărut definitiv ${ }^{42}$, iar

moment tămâiază deja diaconul şi nu din faţa Sfintei Mese, ci din spatele ei; vezi $B \Theta \Lambda$, p. 63. Dar, dacă nu este diacon, preotul continuă singur cădirea şi la intercessio pentru adormiţi, rămânând în faţa Sfintei Mese, de unde rosteşte întreaga anafora.

40 În special după Sinodul IV Ecumenic dipticele au devenit o chestiune eclesiologică majoră, iar numele scrise în ele (vii sau adormiţi) erau sub control strict canonic; vezi Diptice, p. 42 ş.a.

${ }^{41}$ Dipticele, pp. 1-6.

42 O Diataxă de la sfârşitul sec. XIII încă menţionează după ecfonisul „Mai

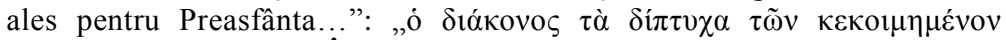

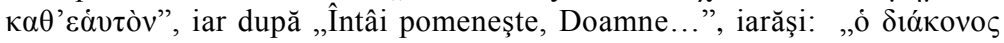

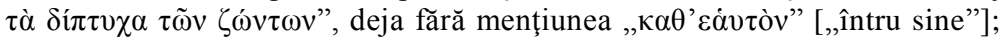


cele pentru vii au fost reformulate într-o cerere generală ${ }^{43}$ sau sunt reduse la lista întâi-stătătorilor Bisericilor Autocefale şi se citesc doar la liturghiile săvârşite de aceștia ${ }^{44}$.

7) Începând cu epoca pre-iconoclastă, în special în Liturghiile bizantine, se observă o sistematizare şi diferenţiere a mijlocirilor pentru cei adormiţi în următoarea ordine:

a) 9-10 cete de sfinţi (fără nume): strămoşi, părinţi, patriarhi...;

b) „Mai ales cu/pentru Preasfânta, Curata...” - care încheie cetele generale de sfinţi şi deschide şirul pomenirilor nominale ${ }^{45}$;

vezi Krasnoselțev, p. 27. Deja în Diataxa lui Filothei Kokkinos, de la jumătatea sec. XIV (vezi Diataxis Vatopedina, p. 72), în acelaşi context

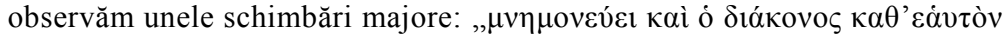

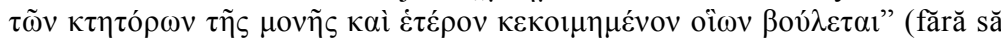
mai fie folosit cuvântul „diptic”) şi numai dacă este Liturghie arhierească, diaconul trebuie să spună cu voce tare formula de încheiere: „K $\alpha$ ì $\tilde{\omega} v$

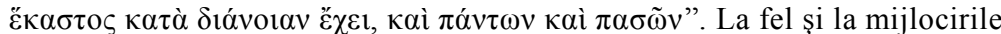
pentru vii, dacă este slujbă arhierească, după „Întâi pomeneşte,

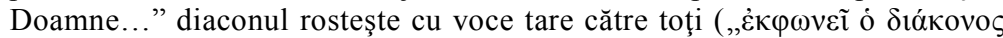

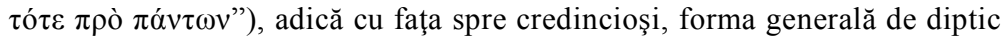
(fără a folosi acest termen), aşa cum o întâlnim descrisă şi la R. Taft

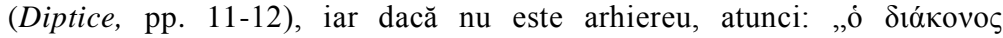

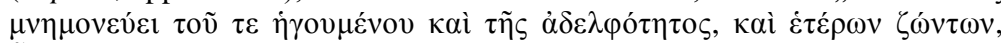

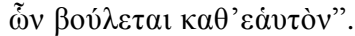

43 Există mai multe forme ale acestei cereri generale, rostite cu precădere la slujbele arhiereşti, dintre care cea mai uzuală, folosită de greci chiar şi la slujbele preoţeşti este: „Şi pe cei pe care fiecare îi are în cugetul său; şi pe toţi şi pe toate"; vezi Diptice, pp. 9-16.

${ }^{44}$ Aceste pomeniri ale întâi-stătătorilor de Biserici autocefale (care în Grecia se pot pune şi la Liturghii arhiereşti obişnuite, nu doar la cele ,patriarhale”) se rostesc în trei momente diferite: înainte de „Sfinte Dumnezeule...” (aclamaţie diaconală/ $\varphi \eta \dot{\mu} \eta)$, apoi de către întâi-stătător la Intrarea Mare şi la „,Intâi pomeneşte, Doamne..."; vezi Dipticele, pp. 3-4.

${ }^{45} \mathrm{La}$ fel şi în cazul mijlocirilor pentru vii, se pun mai întâi cererile generale (rostite de preot), iar pomenirile nominale încep cu „Întâi pomeneşte, Doamne, pe episcopul nostru (N)...", după care ar trebui să urmeze şi restul dipticului oficial pentru cei vii, rostit de către diacon de pe amvon/solee (vide supra, nota 42). Prin urmare, răspunsul ,Şi pe toţi şi pe toate” încheia vechile pomeniri nominale (însoţite de cântarea „Doamne, 
c) dipticul oficial pentru cei adormiți, rostit de diacon cu voce tare de pe amvon, în prezent dispărut şi reformulat prin...

d) ...Pomenirea Sf. Ioan Botezătorul, a anumitor apostoli ${ }^{46}$ şi sfinţi locali + sfântul/sfinţii zilei - pomenire încheiată de formula tip

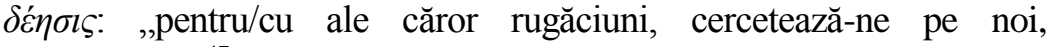
Dumnezeule" 47 ;

e) mijlocirea generală pentru alţi adormiţi (necanonizaţi), cu cererea de odihnă a sufletelor lor şi chiar de iertare a păcatelor ${ }^{48}$;

f) alte pomeniri nominale ale celor adormiţi, în primul rând ctitori şi foşti clerici ai acelui locaş, făcute de diacon în taină $\left(\kappa \alpha \theta^{\prime} \varepsilon \dot{\alpha} v \tau \dot{\partial} v\right)$; fiecare Biserică locală are obiceiuri diferite privind forma şi locul acestor pomeniri ${ }^{49}$.

miluieşte"), iar dispariţia acelor pomeniri a făcut ca răspunsul să vină imediat după ,Intâi pomeneşte, Doamne...”, pierzând sensul de odinioară (scurte detalii vezi în LOIA, pp. 170-174).

46 Aşa se explică faptul că ceata ,apostolilor” este amintită şi în şirul celor 9/10 cete de dinainte de „Mai ales pentru Preasfânta...”, dar şi după aceasta, unde cele mai multe anaforale au fie numele celor 12/13 apostoli, fie doar ale celor care au adus Evanghelia în acele ţinuturi. Doar Liturghiile bizantine îi pomenesc a doua oară pe apostoli la modul general, formalizând cumva acel $\delta \varepsilon ́ \eta \sigma ı \varsigma$ despre care vorbea S. Parenti; vezi PARENTI, p. 400.

47 După cum observă S. Parenti, vechile anaforale nu aveau această formă de

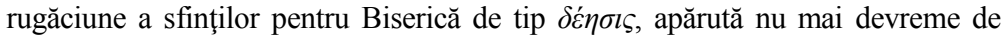
sfârşitul sec. V, odată cu, sau imediată după, introducerea oficială a pomenirii Maicii Domnului (,Mai ales pentru Preasfânta...”) de către patriarhul Ghenadie I al Constantinopolului (458-471), ca reacţie la refuzul patriarhului Martirie al Antiohiei de a recunoaşte termenul ,Theotokos”; vezi PARENTI p. 391, 400, 441.

${ }^{48}$ CHR şi VAS au o formulă comună de mijlocire: "Şi pomeneşte pe toţi cei mai dinainte adormiţi întru nădejdea învierii şi a vieţii veşnice, şi-i odihneşte unde străluceşte lumina feţei Tale". După cum semnalează P. Trempelas, mai multe manuscrise ateniene şi nu numai, au şi adaosul: „Iartă-le lor toate greşelile cele de voie şi cele fără de voie”. (vezi TREMPELAS, p. 120).

49 Slujebnicul slavo-rus conţine cea mai veche şi mai scurtă rubrică: «dḯísonz

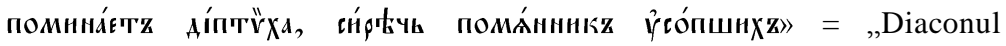
pomeneşte dipticele, adică pomelnicul adormiţilor”, fără să menţioneze nici măcar cădirea, pe care, la ruşi, diaconii o fac în jurul Sfintei Mese, la proscomidiar şi la Tronul Înalt, după modelul celorlalte cădiri. Ieratikonul grecesc (vezi indicaţia după ediţia din 1962 în Diptice, p. 8) prevede: „Şi dând diaconului cădelniţa, acesta cădeşte împrejur Sfânta Masă, pomenind, întru sine, pe cine vrea dintre cei vii şi dintre cei morţi” - amestecând sau, 
Aşa cum vom vedea mai jos, în special în ritul bizantin, pomenirile nominale pentru vii şi adormiţi (dipticele şi cataloagele), au emigrat spre prothesis. Riturile liturgice care nu au un prothesisofertoriu au menţinut sau chiar au dezvoltat în timp (inclusiv pentru a exprima anumite idei dogmatice mai târzii) mijlocirile de la anafora, care întrec prin lungime şi bogăţia ideilor mijlocirile scurte ale anaforalelor bizantine.

\section{Mijlocirile şi pomenirile pentru adormiţi în diferitele formulare euharistice}

O abordare liturgică serioasă implică, în mod obligatoriu, cunoaşterea şi analiza textelor evhologice ale acestor mijlociripomeniri, şi nu doar în Liturghiile bizantine, ci şi în alte tradiţii liturgice locale din Răsărit şi Apus. În acest demers ne vom folosi de textele critice ale liturghiilor şi anaforalelor vechi creştine editate în colecţia „Prex Eucharistica” ${ }^{50}$, dar şi de alte texte şi

cel puţin, inversând, ordinea pomenirilor. Cea mai extinsă şi mai clară rubrică o avem în Liturghierul românesc (vezi Liturghier p. 178), unde se spune: „Preotul dă cădelniţa diaconului, iar acesta tămâiază mai întâi împrejurul Sfintei Mese, Proscomidiarul (unde pomeneşte pomelnicul bisericii pentru cei adormiți), Tronul cel de sus, Altarul, preot şi pe cei din Altar, iar dacă nu este diacon, preotul cădeşte numai în faţa Sfintei Mese. Lăsând apoi cădelniţa, diaconul merge [iarăşi] la Proscomidiar şi citeşte şi pomelnicul bisericii pentru cei vii". Observăm că doar românii au indicaţia de a merge la proscomidiar, unde, în mod tradiţional, se află dipticele (două plăci fixate pe perete) şi restul pomelnicelor, iar dacă nu este diacon, reiese că preotul lasă toate acele nume nepomenite. $\mathrm{O}$ altă particularitate a Bisericii Ortodoxe Române constă în faptul că, la slujbele arhiereşti, unul sau doi diaconi merg la Locul Înalt (lângă colţurile de sus ale Sfintei Mese) şi tămâiază spre arhiereul slujitor în timp ce acesta îşi pomeneşte superiorul (mitropolitul sau patriarhul), apoi primul dintre preoţi îl pomeneşte pe ierarhul celebrant.

${ }^{50}$ A se vedea ediţia lui Anton HäNGgI, Irmgard PAHL, Prex eucharistica: textus $e$ variis liturgiis antiquioribus selecti, Fribourg, 1968. Cu mult înainte de aceasta în occident existau ediţiile lui Jacob Goar (1601-1653), Eusèbe Renaudot (1646-1720), Joseph Aloys Assemani (1710-1782), William Palmer (1803-1885), Charles Anthony Swainson (1820-1887), Frank Ernest Brightman (1856-1932) ş.a, iar în Rusia - [CVL] „Colecţia vechilor liturghii 
ediţii, din care vom selecta fragmentele care ne interesează, pentru a prezenta sistematic diversele forme euharistice de pomenire a celor adormiţi.

Uneori vom prezenta contextul mai larg al acestor mijlociri pentru adormiţi pentru a vedea felul în care acesta se intercalează cu pomenirile sfinţilor sau cu diverse cereri pentru cei vii. Ordinea textelor nu are cum să fie una cronologică, pentru că despre nici o liturghie nu se ştie exact când a apărut în forma primară şi când a ajuns ea în forma de astăzi, ci le vom prezenta în funcţie de tradiţiile liturgice locale, chiar dacă şi o astfel de împărţire, cel puţin în unele cazuri, este relativă şi discutabilă.

\section{Tradiţia alexandrină (egipteană /coptă /etiopiană) ${ }^{51}$}

a) Se pare că cel mai vechi text liturgic alexandrin care conţine o mijlocire pentru adormiţi în anafora este Liturghia din Evhologhiul lui Serapion de Thmuis (sec. IV) ${ }^{52}$ :

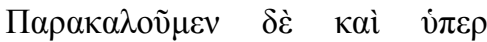

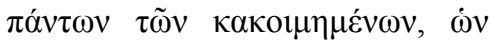

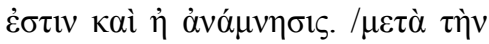

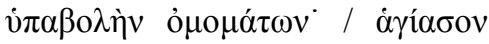

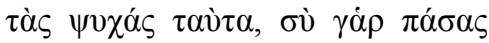

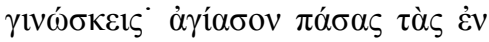

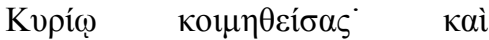

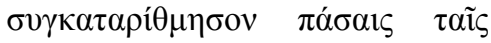

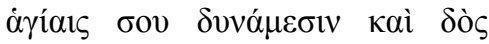

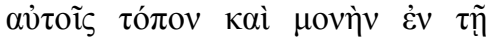
$\beta \alpha \sigma i \lambda \varepsilon i ́ \alpha$ бov.
Ne mai rugăm şi pentru toţi cei adormiţi, a căror pomenire se face [aici]. / [Şi] după rostirea numelor: / Sfinţeşte aceste suflete, că Tu le cunoşti pe toate. Sfinţeşte toate [sufletele] cele adormite în Domnul, numără-le împreună cu toate sfintele Tale puteri, şi dă-le loc şi sălaş în Împărăţia Ta.

b) Un al doilea text ajuns până la noi este fragmentul anaforal de pe Papirusul de la Biblioteca din Strasbourg ${ }^{53}$ şi care,

răsăritene şi apusene” (rus), editată în mai multe fascicule în sec. XIX şi reeditată integral la Moscova în 2007.

${ }^{51} P E$, pp. 101-202. O mică parte din aceste texte au fost traduse de diac. Ioan ICĂ jr. în CO1. Vezi şi Maxwell Johnson, „Liturgy in Early Christian Egypt”, în Join Liturgical Studies, 33, Grove Books, 1995.

52 JoHnSON, p. 254; AL §1406/17-18, pp. 409-411. Traducerea românească: CO1, p. 872.

${ }^{53} A L \S 4713$, p. 258. 
conform ultimelor cercetări, nu ar fi o anafora distinctă, ci o variantă mai veche a Liturghiei Sf. Apostol Marcu ${ }^{54}$.

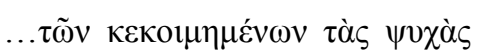

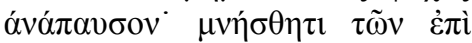

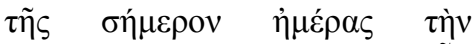

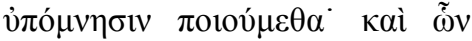

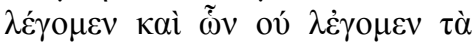
óvó $\mu \alpha \tau \alpha$. ...sufletele celor adormiţi le odihneşte. Adu-Ţi aminte de cei a căror pomenire o facem astăzi, de cei ale căror nume le rostim şi de cei ale căror nu le rostim... 55

c) În Anaforaua Sf. Apostol Marcu ${ }^{56}$ în care, aşa cum spuneam şi mai devreme, mijlocirile şi dipticele sunt plasate înainte de Sanctus şi epicleză ${ }^{57}$ : Iată textul acestui intercessio:

Diaconul: Odihneşte, Doamne, sufletelor celor ce au adormit în credinţa lui Hristos.

[Poporul: Sufletele (lor) le odihneşte!]

Preotul: Sufletele părinţilor şi fraţilor noştri, care mai înainte au adormit în credinţa lui Hristos, le odihneşte, Doamne, Dumnezeul nostru.

Pomeneşte, Doamne, pe sfinţii cei din veac, strămoşi, părinţi, patriarhi, proroci, apostoli, mucenici, mărturisitori, învăţători, episcopi, cuvioşi, drepţi, şi tot duhul ce s-a săvârşit în credinţa lui Hristos, şi pe cei a căror pomenire o facem în ziua de astăzi, şi pe sfântul nostru părinte Marcu, Apostolul şi Evanghelistul, care ne-a arătat nouă calea mântuirii.

Harul Preasfântului Duh [să fie] cu voi cu toţi, fraţilor!

[Diaconii:] Amin. (Diaconul zice dipticele celor morţi).

Iar preotul, plecându-se, continuă: Şi sufletelor acestora şi ale tuturor [celor adormiţi] le dă odihnă,

54 Михаил ЖЕлтов, „Литургия апостола Марка”, în Православная Эничиклопедия, vol. 41, pp. 253-254.

55 JOHNSON, p. 258; CO1, p. 878.

56 Geoffrey J. Cuming, The Liturgy of St Mark, în „OCA”, 234, Roma, PIO, 1990; Cezar LoGIN, „Liturghia grecească a Sfântului Apostol Marcu: Anaforaua, riturile premergătoare împărtăşirii, Împărtăşirea, mulţumirea şi riturile finale, partea II-a", în Altarul Banatului, 1-3/2009, pp. 42-58; AL §4702.

${ }^{57}$ М. ЖЕЛтов, „Литургия апостола Марка”, pp. 258-259. 
Stăpâne, Doamne Dumnezeul nostru, în locaşurile sfinţilor Tăi, în împărăţia Ta dăruind lor şi toate cele bune făgăduite, pe care ochiul nu le-a văzut şi urechea nu le-a auzit şi la inima omului nu s-au suit, pe care le-ai gătit, Dumnezeule, celor ce iubesc (1 Cor. 2,9) numele Tău cel sfânt; Însuţi, fã odihnă, Doamne, sufletelor lor şi îi învredniceşte de împărăţia cerurilor. Iar vieţii noastre sfârşit creştinesc şi bine-plăcut şi fără de păcat dăruieşte şi ne dă nouă parte şi moştenire cu toţi sfinţii Tăi ${ }^{58}$.

d) În Anaforaua Sf. Chiril al Alexandriei, care este de fapt o prelucrare coptă a Liturghiei Sf. Marcu, avem următorul text ${ }^{59}$ :

Dă odihnă sufletelor părinţilor şi fraţilor noştri adormiţi... / pomenirea sfinţilor şi a Născătoarei /

Adu-Ţi aminte, Doamne, de sfinţii noştri părinţi, episcopii ortodocşi adormiţi în credinţă $(\mathrm{N})$. Acestora şi fiecăruia dintre cei pe care i-am pomenit, celor pe care nu iam pomenit şi celor pe care fiecare i-a pomenit în inima sa, dă-le sufletelor lor odihnă în sânul sfinţilor noştri părinţi Avraam (Lc. 16, 22), Isaac şi Iacov. Adună-i în loc cu verdeaţă la apa odihnei $(P s .22,2)$, în raiul desfătării $(F c .3$, $23)$, de unde a fugit toată durerea, înstristarea şi suspinarea $(I s .35,10 ; 51,11)$ în strălucirea sfinţilor Tăi. Învie şi trupul lor în ziua pe care ai rânduit-o după făgăduinţele Tale adevărate şi neminciunoase. Dă-le cele pe care ochiul nu lea văzut, urechea nu le-a auzit şi la inima omului nu s-a suit, pe care le-ai pregătit celor ce iubesc (1 Cor. 2, 9) sfântul Tău Nume. Căci pentru robii Tăi nu va fi moarte, ci mutare. Şi dacă au păcătuit sau greşit ceva ca oameni îmbrăcaţi în trup şi trăitori în această lume, Tu ca un Dumnezeu bun şi milostiv iartă-i, că nimeni nu va fi curat de păcat, nici de-ar fi viaţa lui doar o singură zi (Iov 14, 4-5). În locul acela du la Tine, Doamne, sufletele tuturor şi dă odihnă tuturor celor vrednici de Împărăţia Ta cea cerească. Iar nouă, Doamne, sfârşit creştinesc şi bineplăcut Ţie.

${ }^{58}$ C. LoGIN, „Liturghia grecească a Sfântului Apostol Marcu...”, p. 6; CO1, p. 880.

${ }^{59}$ CO1, p. 885-886. 
e) În Anaforaua alexandrină a Sf. Vasile cel Mare ${ }^{60}$ :

După pomenirea Născătoarei şi a sfinţilor..., diaconul spune dipticele (pentru cei morţi).

Preotul spune în el însuşi ${ }^{61}$ : De asemenea, adu-Ţi aminte, Doamne, şi de toţi cei care au adormit mai înainte întru preoţie şi de cinurile laice; învredniceşte sufletele tuturor să se odihnească în sânurile sfinţilor părinţilor noştri Avraam, Isaac şi Iacov. Întoarce-le şi adună-le în loc de verdeaţă, la apa odihnei $(P s .22,2)$ în raiul desfătării, de unde au fugit durerea, întristarea şi suspinarea $(I s .15,10)$, în strălucirea sfinţilor Tăi.

Iar după ce diaconul termină dipticele, preotul spune: Sufletele celor pe care i-ai primit acolo odihnește-le, Doamne, şi învredniceşte-le de Împărăţia cerească. Iar pe noi, care pribegim aici, păzăşte-ne în credinţa Ta şi călăuzeşte-ne în Împărăţia Ta... ${ }^{62}$

f) În Anaforaua Sf. Grigore de Nazianz ${ }^{63}$, adresată în mod original Fiului, nu Tatălui:

(După pomenirea cetelor de sfinţi, a Născătoarei şi pomenirea nominală a unor sfinţi,) preotul zice întru sine:

Pomeneşte-i, Doamne, pe cei mai înainte adormiţi întru dreapta credinţă părinţi şi fraţi ai noştri, şi odihneşte

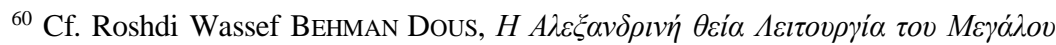

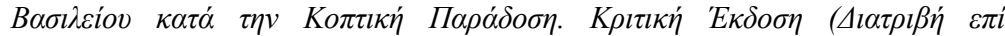
$\triangle \imath \delta \alpha \kappa \tau o \rho i ́ \alpha), \Theta \varepsilon \sigma \sigma \alpha \lambda \sigma v i ́ \kappa \eta, 1997$. Interesant este că anaforaua acestei Liturghii, conform unei tradiţii vechi, se numeşte ,proscomidie” (vezi p. 96), ceea ce nu trebuie confundat cu prothesis-ul bizantin, care în această liturghie coptă este

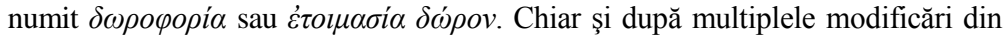
sec. IX-XV, făcute în acord cu tradiţia liturgică coptă, prothesis-ul copt nu s-a dezvoltat după modelul celui bizantin, ci a păstrat sobrietatea primară.

${ }^{61}$ Adică, în timp ce diaconul rosteşte dipticele oficiale cu voce tare, preotul spune rugăciunea de mijlocire în taină.

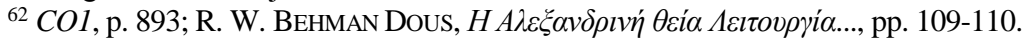

${ }^{63}$ Cezar Login, „Anaforaua Sfântului Grigorie de Nazianz”, în Studia Universitatis Babeş-Bolyai, Theologia Orthodoxa, 2/2009, pp. 218-220; Chiril Lovin, Liturghia Sf. Grigore Teologul. Studiu introductiv, traducere şi comentariu, în

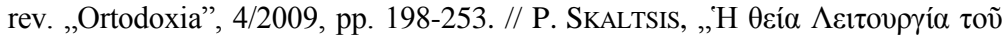

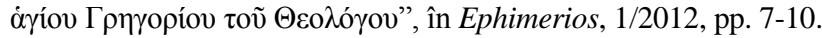


sufletele lor cu cei cuvioşi, cu drepţii. Aşează-i şi îi adună la loc cu verdeaţă, la apa odihnei (Ps. 22, 2), în raiul desfătării, şi împreună cu aceştia şi pe cei ale căror nume le rostim.

Şi sunt pomeniţi cei vii şi cei morţi. Iar după diptice, preotul zice:

Pomeneşte-i, Doamne, pe cei pe care i-am pomenit şi pe cei pe care nu i-am pomenit, credincioşi şi dreptslăvitori, dimpreună cu care şi pe noi, ca un Dumnezeu bun şi de oameni iubitor.

f) Actuala Liturghie etiopiană comună (diferită de vechea Liturghie etiopiană din sec. V, care avea intercessio doar după epicleză, dar fără pomeniri speciale pentru cei adormiţi ${ }^{64}$ ) are acum mai multe pomeniri şi cereri. În Prefatio, unde se sugerează că jertfa se aduce prin mijlocirile sfinţilor, credincioşii răspund:

„Miluieşte, Doamne, sufletele robilor şi roabelor Tale, care au mâncat Trupul Tău şi au băut Sângele Tău, şi au aflat odihnă întru credinţa Ta"65.

Apoi preotul continuă intercessio (aşezat după modelul alexandrin înainte de Sanctus) şi, la un moment dat zice:

Fă odihnă [Doamne,] şi părinţilor şi fraţilor noştri, care au adormit şi s-au [de]săvârşit în credinţa ortodoxă; binecuvântează pe cei care vin la Tine cu tămâie, cu pâinea aducerii, cu vin şi untdelemn, cu acopereminte, cu cărţile care se citesc în biserică şi cu vasele altarului, ca Hristos, Dumnezeul nostru, să le ridice pe ele în Ierusalimul ceresc, şi pe toţi care s-au adunat şi aşteaptă mila lui Hristos, Dumnezeul nostru. Pomeneşte şi pe cei care ne-au dat milostenie, iar la înfricoșătoare Judecata Ta fii milostiv către ei. Izbăveşte, Dumnezeul nostru, după mare mila Ta, toate sufletele împovărate şi necăjite, pe întemnitaţi şi ostatici, pe cei exilaţi, pe cei duşi în robie şi pe cei puşi la munci grele.

${ }^{64}$ Vezi reconstrucția lui MERCER, pp. 117-137.

${ }^{65}$ CVL, p. 485 . MERCER, p. 313. 
Iar la sfârşitul mijlocirilor preotul spune: Pe noi şi pe toți cei adormiţi miluieşte-i Tu, Care ai trimis pe Fiul Tău în sânurile Fecioarei ${ }^{66}$.

După epicleză urmează un alt intercessio mai concis, în care preotul, după ce pomeneşte patriarhul, episcopul şi regele, încheie anaforaua zicând:

„Pomeneşte, Doamne, pe toţi cei ce au adormit şi odihnesc întru credinţa în Hristos şi adună sufletele lor în sânul lui Avraam, Isaac şi Iacov. Izbăveşte-ne şi pe noi de tot păcatul şi blestemul, de toată minciuna şi călcarea de jurământ, de orice părtăşie cu ereticii şi păgânii stricători de credinţă. Dăne nouă inimă şi pricepere, ca să fugim de toată lucrarea satanei; dă-ne nouă să împlinim voia Ta în toată vremea şi scrie numele noastre împreună cu toţi drepţii şi mucenicii în Împărăţia Cerurilor, prin Iisus Hristos Domnul nostru, cu Care Ţi se cuvinte slava şi stăpânirea, împreună şi cu Duhul Sfânt, acum şi pururi şi în vecii vecilor. Amin"67.

2. Tradiţia ierusalimiteană ${ }^{68}$

a) În Anaforaua greacă Sf. Iacov fratele Domnului ${ }^{69}$, după pomenirea Născătoarei şi a multor categorii şi nume de sfinţi, preotul continuă mijlocirile generale:

Adu-Ţi aminte, Doamne, şi de sfinţii noștri părinţi care au fost omorâţi de barbari în sfântul munte Sinai şi în Raith,

${ }^{66}$ CVL, 486-487; MERCER, p. 351-352.

${ }^{67}$ CVL, p. 492 . MERCER, p. 359.

${ }^{68}$ Brightman include tradiţia ierusalimiteană în cea siriacă; vezi BRIGHTMAN pp. 31.

${ }^{69}$ Prima ediţie critică a acestei liturghii aparţine lui MERCIER (1946), de unde a tradus şi diac. Ioan Ică Jr. în CO1, p. 903. După noile descoperiri de la Sinai din 1975, ediţia din 1946 şi-a pierdut actualitatea, iar noile cercetări ale Liturghiei greceşti a Sf. Iacov trebuie neapărat să ţină seama de lucrarea lui KAZAMIAS. De asemenea este important să nu neglijăm tradiţia georgiană a acestei liturghii, unde ea s-a slujit fără întrerupere până în sec. IX; vezi Stéphane VERHELST, La Liturgie de Saint Jacques, Rétroversion grecque et commentaires, col. „Jerusalemer Theologisches Forum”, 17, Münster, Aschendorff Verlag, 2011. 
şi de ceilalţi cuvioşi părinţi ai noştri ortodocşi, şi de toţi sfinţii, nu pentru că am fi vrednici să-i pomenim pe ei, fericiţii, ci pentru ca şi ei, care stau înaintea înfricoşătorului şi cutremurătorului Tău scaun de judecată, să ne pomenească în schimb pe noi cei vrednici de milă.

Adi-Ţi aminte, Doamne, de preoţii, diaconii, diaconiţele $^{70}$, ipodiaconii, citeţii, exorcişti, predicatori/ tâlcuitori, cântăreţi, monahi, fecioare, văduve, orfani, nevoitori şi de toţi cei care prin credinţă, în părtăşie/ comuniune cu Biserica Ta cea sfântă, sobornicească şi apostolică s-au săvârşit.

Adu-Ți aminte, Doamne, de preaevlavioşii şi credincioşii împăraţi $[\ldots]$ şi de cei care au împărăţit după ei cu cucernicie şi credinţă, şi de toţi laicii ortodocşi care au adormit în credinţă şi cu pecetea lui Hristos.

Adu-Ți aminte, Doamne, de părinţii, prietenii şi rudele noastre.

Şi după ce [diaconul $\left.{ }^{71}\right]$ pomeneşte câţi [adormiţi] ortodoçsi vrea, [preotul] zice:

Adu-Ţi aminte, Doamne, Dumnezeul duhurilor şi a tot trupul $(N m .16,22)$, de toţi ortodocşii pe care i-am pomenit şi pe care nu i-am pomenit [de la dreptul Abel şi până acum, $]^{72}$ şi Tu Însuţi îi odihneşte în pământul celor vii $(P s .113,17)$, în Împărăţia Ta, în desfătarea raiului $(I z .28,13)$, în sânurile lui Avraam (Lc. 16, 22), Isaac şi Iacov, şi ale sfinţilor noştri părinţi, de unde a fugit durerea, întristarea şi suspinarea (Is. $35,10)$, unde priveşte şi străluceşte tot timpul lumina feţei Tale (Ps. 4, 7). Îndreptează în pace sfârşitul vieţii noastre...

${ }^{70}$ Ceata diaconiţelor nu este pomenită în manuscrisele sinaitice, întrucât acestea erau folosite cu precădere în mănăstirile de călugări; vezi KAZAMIAS, p. 207 comparativ cu MERCIER, p. 218 şi PE, p. 258.

${ }^{71}$ Manuscrisele sinaite (vezi KAZAMIAS, p. 207) precizează că în acest moment se

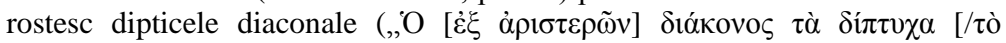

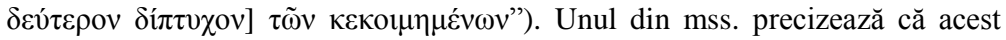
lucru îl face diaconul din stânga (nota 18), iar altul - că acesta ar fi deja al doilea diptic (nota 17), dar nu e clar dacă este al doilea după cel pentru vii sau un al doilea pentru cei adormiţi. MERCIER şi $P E$ nu fac această precizare şi rămâne neclară repartizarea rolurilor între diacon şi preot.

${ }^{72}$ O expresie pe care am întâlnit-o în BRIGHTMAN, p. 57 şi $C V L$, p. 151, dar care nu am putut-o identifica în ediţiile critice ale IAC, ci doar în Liturghia celtică. 
b) Liturghia siriacă a Sf. $\operatorname{Iacov}^{73}$ are cele mai multe şi mai extinse pomeniri ale celor adormiţi. Pentru frumuseţea şi originalitatea textelor, redăm fragmentele cele mai importante ${ }^{74}$ :

\section{(La prothesis,) însemnând cu Crucea pâinea euharistică} adusă de diacon, preotul spune următoarea rugăciune $e^{75}$ :

Dumnezeule Cel din veci mare şi minunat, Care primeşti aduceri de jertfe, făgăduinţe, pârgă şi zeciuieli de la credincioşii robii Tăi, primeşte, Doamne, (şi) aducerea robilor Tăi, pe care ei le-au ales şi le-au adus din dragoste pentru Tine şi pentru numele Tău cel sfânt; păzeşte-i şi-i binecuvântează cu toate binecuvântările duhovniceşti; mângâie-i cu bunătăţile cele neîmpuţinate şi cu nădejdea făgăduinţelor date sfinţilor Tăi. Revarsă binecuvântarea Ta şi peste toate ale lor, dă-le sănătate şi înfrânare trupurilor lor, curăţie şi sfinţenie sufletelor, iar pe cei adormiţi (dintre ei) odihneşte-i pe veci în locaşurile celor fericiţi ai Tăi şi, în schimbul bunătăţilor trecătoare ${ }^{76}$, dă-le lor viaţă [veşnică] şi Împărăţia [Ta]. Amin.

Apoi preotul luând pâinea cu ambele mâini zice:

Dumnezeule, Care ai primit jertfa de la Abel pe câmp, de la Noe în corabie, de la Avraam pe vârful muntelui, de la David în

73 Această liturghie a fost tradusă pentru prima dată din greacă în siriacă de Mar Yaqob Burdana/Iacob Buradaeus (505-578), apoi corectată şi sistematizată de Iacob din Edessa (640-708). Alte adăugiri s-au făcut de către Moses Bar Kepha, episcop de Mosul (sec. IX), apoi de către Mar Dionysius Bar Salibi, episcop de Amid (sec. XII). Din cauza adaosurilor exagerate, în sec. XIII Mar Greogorios Bar Habraeus redactează o variantă lungă şi alta scurtă, iar o ultimă redactare a acestor variante este făcută în 1575-1591; vezi ABBA SERAPHIM OF GLASTONBURY, „An Introduction To The Liturgy of Saint James", în The Glastonbury Review, 125/2014, publicat pe www.britishorthodox.org/miscellaneous/an-introduction-tothe-liturgy-of-saint-james/ [accesat: 26.02.2021]

74 Cf. CVL, pp. 165-203, traducere făcută după E. RENAUDOT, Liturgiarum Orientalium Collectio, vol. II, Francoforti ad Moenum, 1847, pp. 1-12, 29-42. Spre deosebire de această veche Liturghie siro-iacobită, Brightman a editat „Liturgia minor S. Jacobi” în care pomenirile pentru cei adormiţi sunt mult mai puţine şi mai scurte.

${ }^{75}$ CVL, 172.

${ }^{76} \mathrm{O}$ posibilă referinţă la darurile euharistice şi, în general, la milostenia care se dă pentru adormiţi. 
aria lui Aravna Iebuseul (2 $R g$. 24), de la Ilie pe Muntele Carmelului şi banul văduvei în vistieria [Templului], Însuţi Doamne, primeşte şi aceste ofrande, care se aduc prin mâinile mele ale neputinciosului şi păcătosului, şi prin ele ${ }^{77}$ pomeneşte întru amintire bună pe cei vii şi adormiţi, pentru care ele se aduc, şi binecuvântează viaţa celor care le aduc. Amin.

După Trisaghion, inainte de lecturi, diaconul: Pentru liniştea şi pacea tuturor celor care cred în Hristos, de la o margine a lumii şi până la alta, pentru cei slabi şi asupriţi, şi pentru cei ce pătimesc; pentru părinţii, fraţii şi învăţătorii noştri; pentru [iertarea] greșelilor şi faptelor noastre (ale tuturor), şi pentru credincioşii adormiţi care au plecat dintre noi; cu aducere de tămâie, Domnului să ne rugăm ${ }^{78}$.

Preotul, însemnând poporul cu crucea, zice rugăciunea pentru citirea Evangheliei ${ }^{79}$ :

Dreapta Domnului nostru Iisus Hristos şi mâna stăpânirii Sale şi puterea ascunsă a măreției Lui, care dă toate binecuvântările şi darurile [necesare/de trebuinţă] vieţii, care a odihnit peste sfinţii apostoli în sfântul foişor din Sion şi care i-a sfinţit şi i-a binecuvântat pe Muntele Măslinilor, să vină, să se sălăşluiască şi să odihnească peste fraţii mei, cititorii şi ascultătorii [Evangheliei], să păzească ţara aceasta şi pe toţi credincioşii care locuiesc în ea, oraşul acesta şi pe credincioşii ei cetăţeni, să dăruiască fericită odihnă credincioşilor adormiţi, plecaţi de aici, iar pe cei care vieţuiesc aici, să-i păzească în veci. Poporul: Amin.

Inainte de Crez, preotul: Pomenește, Doamne, pe cei adormiţi şi-i odihneşte pe cei care s-au îmbrăcat în Tine prin botez şi care Te-au primit de la jertfelnic ${ }^{80}$.

La anafora, după toate mijlocirile pentru vii se trece la pomenirea Născătoarei şi a sfintilor ${ }^{81}$ :

Încă pomenim pe toţi credincioşii adormiţi în dreapta credinţă, trecuţi şi de la acest sfânt altar, din această localitate şi din toate ţările, care mai înainte au adormit şi

\footnotetext{
77 Adică prin ,,aduceri”.

${ }^{78}$ CVL, p. 174.

${ }^{79}$ CVL pp. $180-181$.

${ }^{80}$ CVL, p. 182.

${ }^{81}$ CVL, pp. $195-196$.
} 
care, odihnind în credinţa adevărată, au trecut la Tine, Dumnezeul şi Domnul duhurilor şi a tot trupul. Cerem, cădem şi rugăm pe Hristos Dumnezeul nostru, care a primit la Sine sufletele şi duhurile lor, ca după mulțimea îndurărilor Sale să-i arate pe ei vrednici de lăsarea greşelilor şi iertarea păcatelor, ca şi pe noi şi pe ei să ne învrednicească a intra în Împărtăţia Cerurilor. Pentru aceasta să strigăm şi să zicem: Kyrie, eleison $(\text { de } 3 \text { ori })^{82}$.

Preotul aplecându-se/înclinându-se zice:

Pomeneşte, Doamne, şi pe preoţii ortodocşi mai înainte adormiţi, pe diaconi şi ipodiaconi, pe psalţi, citeţi, tâlcuitori/predicatori, cântăreţi ${ }^{83}$, exorcişti, monahi, nevoitori, slujitori, fecioare (afierosite) şi mireni, care s-au [de]săvrâşit în dreaptă credinţă şi pe toţi pe care fiecare îi are în suflet. Înălţându-mi glasul, Doamne, Dumnezeul duhurilor şi a tot trupul, pomeneşte-i pe toţi pe care i-am pomenit, ortodocşi plecaţi din această viaţă, dăruieşte-le odihnă sufletelor, trupurilor şi duhurilor lor, izbăvindu-i de osânda cea viitoare şi veşnică, şi făcându-i pe ei vrednici de bucuria din sânurile lui Avraam, Isaac şi Iacov, unde străluceşte lumina feţei Tale, (şi) de unde sunt alungate (/au fugit) toate bolile, întristările şi suspinările. Nu le socoti lor toate păcatele şi nu intra întru judecată cu robii Tăi, pentru că nimeni din cei vii nu este drept înaintea Ta $(P s .142,2)$ şi dintre oamenii care sunt pe pământ, nu este nici unul care să nu fie vinovat de păcat sau curat de întinăciune, decât singur Domnul nostru Iisus Hristos, Unul-Născut Fiul Tău, prin care şi noi nădăjduim să primim îndurare şi iertare de păcate, care ni se dă tuturor prin El/de dragul Lui.

Poporul: Dă-le lor, Dumnezeule, odihnă, milă şi iertare pentru greşelile neştiinţei şi păcatele noastre ale tuturor (făcute) cu ştiinţă şi neştiinţă...

82 Doar această parte am identificat-o la BRIGHTMAN, p. 91, şi în ediţia modernă a Liturghiei; vezi Athanasius Yeshue SAMuEl, The Divine Liturgy of Saint James the First Bishop of Jerusalem according to the rite of the Syrian Orthodox Church of Antioch, [s.1.], 1967, p. 47.

${ }^{83}$ Se presupune că diferenţa dintre psalţi şi cântăreţi consta din faptul că primii cântau doar Psalmi şi alte cântări din Vechiul Testament, iar ceilalţi cântau imne nou-testamentare. 
(După anafora, inainte de „Tatăl nostru”,) diaconul rosteşte cu glas mare [ectenia] sobornicească/catholică $\breve{a}^{84}$ :

Binecuvântează, Doamne! ${ }^{85}$ Iară şi iară, prin această sfântă ofrandă şi jertfă împăciuitoare, care s-a adus lui Dumnezeu-Tatăl, s-a sfinţit şi s-a desăvârşit prin umbrirea Duhului Celui Sfânt şi Viu $\{\ldots\}$, stăruind ne rugăm pentru cinstitul părinte preot, care a adus-o şi a sfinţit-o, şi pentru jertfelnicul lui Dumnezeu pe care aceasta s-a adus, şi pentru binecuvântatul popor care se apropie şi o primeşte cu credinţă, şi pentru cei pentru care ${ }^{86}$ ea a fost adusă şi sfinţită...

[...] Dăruieşte odihnă şi sufletelor celor adormiţi şi fieŢi milă de cei păcătoşi în Ziua judecăţii. Sufletelor celor adormiţi, despărțiţi de noi şi trecuţi din veacul acesta, dăle, Hristoase, odihnă împreună cu sfinţii şi drepţii: să le fie lor Crucea Ta pod, iar botezul Tău acoperemânt; Trupul şi Sângele Tău cel sfânt să le fie lor cale către Împărăţia Ta ${ }^{87}$. Doxologie neîncetată cu închinare dumnezeiască se cuvine a-Ți aduce din mijlocul altarului/sanctuarului Tău - Tatălui şi Fiului şi Duhului Celui Sfânt şi Viu - aşa încât Însuşi adevăratul Dumnezeu să-şi arate bunătatea, bunăvoinţa, milostivirea şi iubirea $\mathrm{Sa}$, de acum şi până-n veac. Să ne rugăm Domnului cu rugăciunea [Lui]. /urmeazăa: „Tatăl nostru"/

(După „Sfintele - sfinţilor”, innainte de împărtăşire,) diaconul: Prin învierea lui Hristos, Împăratul nostru, după credinţă, să primim iertare sufletelor nostre şi să-I spunem împreună Fiului care ne-a mântuit prin Crucea Sa: Binecuvântat eşti Mântuitorul nostru, şi Sfânt, Sfânt, Sfânt eşti Tu, care ai preamărit cinstea Maicii Tale, a sfinţilor şi a credincioşilor adormiţi; Aliluia!

Puterile cereşti stau împreună cu noi în mijlocul altarului/sanctuarului şi împlinesc slujirea Trupului Fiului

\footnotetext{
${ }^{84}$ Aşa se numeşte ectenia pentru toate categoriile în Liturghia Sf. Iacov, atât în cea greacă, cât şi în cea siriacă; $C V L$, p. 197-198.

85 Poate fi o exclamaţie de început asemănătoare celor bizantine: „Binecuvântează, părinte/stăpâne!".

${ }^{86}$ Altă variantă: ,de dragul cărora”.

${ }^{87}$ De obicei se foloseşte expresia „,merinde pe calea spre Împărăţia lui Dumnezeu” şi nu-i exclus ca şi aici să se aibă în vedere anume acest aspect.
} 
lui Dumnezeu, care s-a jertfit în faţa noastră. Apropiaţi-vă şi primţi de la El iertarea păcatelor şi greşelilor; Aliluia!

La sfânt jertfelnicul Tău, Doamne, să se săvârşească pomenirea părinţilor, fraţilor şi învăţătorilor noştri, ca să stea ei de-a dreapta Ta în Ziua arătării măreţiei Tale, Hristoase, Împărate; Aliluia!... ${ }^{88}$

3) Tradiţia orientală (greacă-antiohiană, siriană şi armeană)

a) În Constituţiile Apostolice (sfârşitul sec. IV) mijlocirile pentru cei adormiţi sunt înserate între mijlocirea pentru conducători şi cea pentru popor, fiind nediferenţiate de cele pentru sfinţi:

„Încă Îţi aducem această ofrandă şi pentru toţi sfinţii care Ţi-au bineplăcut din veac, patriarhi, profeţi, drepţi, apostoli, mucenici, mărturisitori, episcopi, presbiteri, diaconi, ipodiaconi, citeţi, cântăreţi, fecioare, văduve, laici şi [pentru] toţi ale căror nume le ştii Tu Însuţị”89.

Abia în ectenia diaconală de după anafora (VIII, 13) apare o cerere mai clară, dar tot alături de sfinţi şi inserată între cererea pentru conducători şi cea pentru timpuri şi roade bune: „Să ne aducem aminte de sfinţii martiri, ca să ne învrednicim să ne facem părtaşi ai luptei lor, şi de cei cei au răposat în credinţă’"90.

Constituţiile Apostolice au şi o scurtă rânduială (extra-euharistică) pentru cei adormţi, compusă dintr-o cerere diaconală extinsă, o rugăciune a episcopului pentru odihna celor adormiţi şi ultima de plecare a capetelor pentru cei care asistă la slujbă (VIII, 61)91.

b) Testamentum Domini (sec. IV-V), printre cererile pentru vii, menţionează doar: "Adu-Ţi aminte de cei ce au adormit în credinţă şi dă-ne/le moştenire împreună cu sfinţii Tăi" ${ }^{92}$.

c) Un exemplu mai special în reprezintă Anaforaua lui Adai şi Mari, unde mijlocirea pentru cei adormiţi nu este explicită, ci implicită în exprimarea eshatologică a roadelor epiclezei:

\footnotetext{
${ }^{88}$ CVL, pp. 200-201.

${ }^{89}$ Cartea VIII, 12, apud CO1, p. 752; BRIGHTMAN, pp. 21-22.

${ }^{90} \mathrm{CO1}, \mathrm{p} .753$.

${ }^{91}$ CO1, pp. $765-766$.

${ }^{92} \mathrm{CO1}$, p. 798.
} 
„Să vină, Doamne, Duhul Tău Cel Sfânt şi să se odihnească peste ofranda robilor Tăi, să o binecuvânteze şi să o sfinţească; ca să fie pentru noi, Doamne, spre ispăşirea datoriilor şi iertarea păcatelor, spre marea nădejde a învierii morţilor şi viaţa cea nouă în Împărăţia cerurilor împreună cu toţi care au bineplăcut Ție" ${ }^{\prime 93}$.

d) Liturghia siriacă a celor 12 apostoli ${ }^{94}$, imediat după epicleză şi, înainte de pomenirile sfinţilor şi ale Născătoarei are următoare mijlocire:

,... Şi pentru toţi fraţii noştri care s-au mutat în dreaptă credinţă, ca să-i aşezi în slava dumnezeiască, neintrând cu ei la judecată, fiindcă nimeni [din cei] vii nu-i nevinovat înaintea Ta (Ps. 142, 2).

Ecfonis: Căci Unul este Cel ce a trăit pe pământ fără păcat (1 In. 2, 12), Unul-Născut Fiul Tău, Domnul nostru Iisus Hristos, marea ispăşire $(1$ Ptr. 4,11$)$ pentru neamul nostru, prin Care nădăjduim să aflăm milă şi iertarea păcatelor [noastre], şi pentru El/de dragul Lui, şi celor adormiţi..." 95

e) În Liturghia lui Nestorie (sec. V), există două şiruri de mijlociri interpuse, în mod original, între Sanctus şi partea de Institutio-Anamnesis-Epiclesis, preluată din Liturghia celor 12 apostoli. Abia în al doilea şir, după enumerarea a zece categorii şi sfinţi şi slujitori (fără Maica Domnului, pe care Nestorie nu o recunoştea ca Theotokos), avem o scurtă cerere pentru cei adormiţi, după care se trece iarăşi la mijlocirile pentru vii:

93 CO1, p. 906; CVL, p. 521. Pomenirea celor adormiţi se repetă într-o formă asemănătoare într-o rugăciune de mulţumire de după împărtăşire $(C V L, \mathrm{p}$. 529), dar care ar putea să fie mai târzie.

94 Aceasta a fost tradusă în siriacă şi dezvoltată dintr-o ipotetică anafora greacă de tip antiohian, numită ,,apostolică” (marcată de specialiști ca $\Omega$-Ap), care a stat şi la baza CHR, dar şi a Liturghiilor lui Nestorie şi Teodor de Mopsuestia; detalii în LOIA, pp. 50-54 şi la PARENTI, pp. 120-121.

95 CO1, p. 896. 
„....pentru toţi fraţii noştri întru Hristos, care au trecut din veacul acesta întru dreaptă credinţă, numele cărora Tu le ştii, lasă şi iartă lor tot ce au greşit sau au nelegiuit înaintea Ta, ca nişte oameni stricaţi/afectaţi de rătăciri şi patimi, pentru solirile celor care Ţi-au bineplăcut Ţie" ${ }^{\prime 96}$.

\section{f) În Liturghia armeană comună (,,Surb Patarag”) ${ }^{97}$ :}

Diaconul: Pentru sufletele celor adormiţi în dreapta şi ortodoxa credinţă, care pentru Hristos s-au [de]săvârşit, Domnului să ne rugăm.

Poporul: Duhule al lui Dumnezeu, care Te cobori din cer! Tu, care prin mâinile noastre săvârşeşti Taina Celui împreunăslăvit cu Tine, pe Tine Te rugăm, ca prin [re]vărsarea sângelui Lui să odihneşti sufletele adormiţilor noştri.

Preotul: Te rugăm şi-Ți cerem pentru sufletele celor adormiţ̧i, pentru sufletele învăţătorilor noştri şi a ctitorilor sfânt locaşului acesta, îngropaţ̧i aici ${ }^{98}$ şi pretutindeni; pentru eliberarea fraţilor noştri aflaţi în robie, pentru bunăstarea celor care sunt de faţă şi pentru odihna celor adormiţi cu credință şi sfinţenie în Hristos, pentru a căror pomenire ne rugăm la această liturghie.

Pomeneşte, Doamne, miluieşte şi binecuvântează poporul care-Ți stă înainte şi-Ţi aduce această jertfă [fără de sânge]: dă-le lor cele necesare şi de folos. Pomeneşte, Doamne, miluieşte şi binecuvântează pe cei ce slujesc şi aduc daruri Sfintei Tale Biserici şi pe cei care-şi aduc aminte de săraci prin milostenii; iar pentru ofrandele ,împrumutate" Ţie, răsplăteşte-le însutit cu darurile Tale cele bogate şi cereşti, aici şi în veacul viitor. Pomeneşte, Doamne, miluieşte şi Te milostiveşte de sufletele celor adormiţi, odihneşte-le, luminează-le şi număre-le cu sfinţii Tăi în Împărăţia cerurilor, învrednicindu-i de mila Ta. Pomeneşte, Doamne, sufletul

${ }^{96}$ CVL, p. 548; $A L \S 4632$, p. 1307.

${ }^{97}$ AL §4746, pp. 1347-1348. H.-J. FeULNER, Die armenische Anaphora des hl. Athanasius. Kritischer Edition, Übersetzung und liturgievergleichender Kommentar, col. „Anaphorae Orientales 1"/ „Anaphorae Armeniacae 1”, Rome, PIO, 2001.

98 În unele versiuni: ,sub umbra/acoperemântul acestei biserici”. 
robului Tău (N) şi-l miluieşte după mare mila Ta, odihneşte-1 întru cercetarea luminii feţei Tale. Pomeneşte, Doamne, pe cei care ne-au cerut să-i pomenim în rugăciuni: vii şi adormiţi, călăuzeşte-le voinţa lor şi a noastră pe calea mântuirii şi răsplăteşte-le tuturor cu bogată şi nesfârşită mila Ta; curăţeşte-ne gândurile noastre, fă-ne pe noi templu [pregătit] pentru primirea Trupului şi Sângelui Unuia-Născut Fiului Tău, Domnul şi Mântuitorul nostru Iisus Hristos, cu Care Ţie, Tată Atoţ̧iitorule, împreună cu Sfầntul şi Bunul şi de-viaţăfăcătorul Tău Duh, se cuvine slava, stăpânirea şi cinstea, acum şi pururi şi în vecii vecilor. Amin.

Pentru comparaţie redăm, tot din ritul armean, şi un fragment din slujba (extra-euharistică) pentru cei adormiţi, echivalentă „Trisaghionului” bizantin:

Preotul: Dă, Hristoase Dumnezeule, odihnă şi îndurare sufletelor celor adormiţi, iar nouă, păcătoşilor, dăruieşte-ne iertarea păcatelor.

Diaconul: Iarăşi, cu pace, să ne rugăm pentru sufletele celor adormiţi, ca Hristos, Mântuitorul nostru, să-i numere cu drepţii, iar pe noi să ne păzească cu harul milostivirii Sale. Atotputernice Doamne, Dumnezeul nostru, apără-ne şi ne miluieşte.

Poporul: Doamne, miluieşte! (de 3 ori). Apoi, preotul rugăciunea:

Hristoase, Fiul lui Dumnezeu, iertătorule şi îndurate, miluieşte, ca un ziditor iubitor, sufletele adormiţilor robilor Tăi $(N)$. Pomeneşte-i pe ei în ziua cea mare a venirii Împărăţiei Tale; învrednicește-i de mila, lăsarea şi iertarea păcatelor; numără-i şi-i preamăreşte împreună cu sfinţ̧ii Tăi, care vor sta de-a dreapta Ta; că Tu eşti Domnul şi ziditorul tuturor făpturilor, şi judecătorul viilor şi al morţilor, şi Ţie se cuvine slavă, putere şi cinste, acum şi pururea şi în vecii vecilor. Amin.

4) Tradiţia bizantină, generalizată în toată Biserica Ortodoxă cel puţin începând cu sec. X-XI (inclusiv în Ierusalim, Georgia şi Alexandria), are în ambele liturghii/anaforale - VAS și CHR - o cerere identică, destul de scurtă, plasată imediat după pomenirea sfinţilor, înainte de mijlocirile pentru cei vii: 
Kà̀ $\mu v \eta ́ \sigma \theta \eta \tau \imath \quad \pi \alpha ́ v \tau \omega v \quad \tau \tilde{\omega} v \mid$ Şi pomeneşte pe toţi cei mai

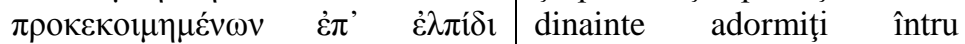

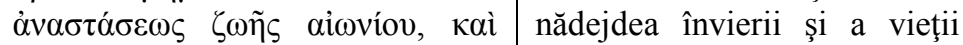

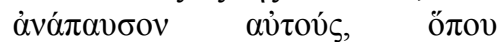

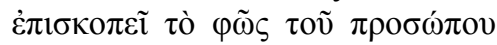
бov.

veşnice; [*iartă-le lor toate greşelile cele de voie şi cele fără de voie $e^{99}$ ] şi-i odihneşte unde străluceşte lumina feţei Tale (Ps. 4, 7).

După cum observă G. Winkler ${ }^{100}$, plasarea mijlocirilor pentru adormiţi înaintea celor pentru vii este o tradiţie comună pentru vechile izvoare siriene: expresia ,[Hristos] va judeca ${ }^{(1)}$ morţii şi ${ }^{(2)}$ viii” este întâlnită în „Faptele lui Toma”, în scrierile lui Afraat şi în Rânduiala siriacă a Botezului, dar şi în vechea redacţie a Liturghiei armene. Cu timpul însă această ordine a pomenirilor a rămas specifică doar Liturghiei bizantine.

De asemenea autoarea observă că prima variantă a mijlocirii vasiliene era şi mai scurtă - ,Şi pomeneşte pe toţi cei mai dinainte adormiţi întru nădejdea învierii şi a vieţii veşnice" - după care a fost îmbogăţită cu cererea: ,şi-i odihneşte unde străluceşte lumina feţei Tale", împrumutată probabil din IAC şi, trecută imediat şi în CHR.

$\mathrm{O}$ analiză a mijlocirilor pentru adormiţi în diferite versiuni ale VAS întâlnim şi în lucrarea lui C. Streza, care prezintă evoluţia VAS în toate variantele ei cunoscute ${ }^{101}$.

5) Tradiţia occidentală

a) Cel mai vechi izvor liturgic din această tradiţie, încă influenţat puternic de izvoarele greceşti, ar fi Missa pro defunctis, de fapt un fragment missal, atribuit Sf. Ilarie de Poitiers $(\uparrow 367)$, descoperit de Christian Karl Josias von Bunsen în Codice

${ }^{99}$ Adaos întâlnit în unele mss. de TREMPELAS, p. 120.

100 Gabriele WinkLER, „The christology of the anaphora of Basilius in its various redactions, with some remarks concerning the authorship of Basilius", în Bryan D. SPINKS (ed.) The place of Christ in liturgical prayer. Trinity, Christology, and Liturgical Theology, Collegeville, Minnesota, Liturgical Press, 2008, pp. 112-126.

101 Ciprian I. StrezA, Anaforaua Sfântului Vasile cel Mare. Istorie-text-analiza comparată, comentariu teologic, Sibiu, Edit. Andreiana, 2013, pp. 373-448. 
Palimpsesto Bibliothecae Sangallensis secundum Niebukrii aprografum $^{102}$. După cum vom vedea, complexitatea textului trădează o origine sau, cel puţin, o prelucrare mai târzie decât epoca Sf. Ilarie. Cu toate acestea, fragmentul are şi elemente foarte vechi şi reprezintă o introducere (prefatio) absolut inedită pentru o anafora. Iată textul:

„Chivernisitorule şi dătătorule al învierii ce va să fie, Dumnezeule, făptuitorule, dătătorule şi distribuitorule al nemuririi, care ai pus hotar vieţii nostre, pentru a ne deschide intrarea în veşnicie, care prin sfârşitul celor prezente ai pus început celor viitoare, şi prin descompunerea celor stricăcioase ai deschis uşile nestricăciunii; Dumnezeule, care ai binevoit ca despărţirea sufletelor ce pleacă din trupuri să nu fie moarte, ci somn, şi însăşi lungimea acestui somn ai întărito cu nădejdea învierii, prin care chipul vieţii celor ce cred în Tine nu încetează, ci se mută, iar viaţa celor aleşi ai Tăi se schimbă, dar nu se nimicește; Dumnezeule, care îi ridici pe cei morţi, fără să fii împiedicat de nici un fel de moarte sau de diferitele împrejurări ale sfârşitului, şi care nu laşi ca făptura mâinilor Tale să piară, căci în orice chip ar muri omul: [fie din] cauza bătrâneții, [fie] furtuna 1-a doborât, focul 1-a ars, păsările 1-au mâncat, fiarele 1-au devorat, pământul 1-a acoperit, prăpastia 1-a cuprins, peştele 1-a înghiţit - toţi vor reveni la cele dintâi şi pământul îi va întoarce vii pe toţi, iar după ce au fost înghiţiţi de stricăciune, vor învia şi se vor îmbrăca în nestricăciune. [Pentru aceasta,] cerem şi Te rugăm, ca duhurile robilor Tăi $(\mathrm{N})$ şi a roabelor Tale $(\mathrm{N})$ să nu fie osândite în întunericul cel mai din afară sau în cuptorul de foc al gheenei sau în frigul neîncetat al tartarului; să nu ajungă în loc de chinuri, ci să se odihnească în sânurile patriarhului Avraam, aşteptând vremea învierii şi ziua judecăţii cu bucuria

${ }^{102}$ Numele atribuit de Ch. Bunsen acestui fragment missal este: „Praeces in missa pro defunctis autore, ut videtur, S. Hilario, Episcopo Pictaviensi”; vezi Hippolytus und seine Zeit: Anfänge und Aussichten des Christenthums und der Menschheit, Brockhaus, 1852. Fragmentul păstrat din această missă a fost tradus în $C V L$, pp. 578-579, de unde a şi fost preluat. 
viitoarei nemuriri, prin Domnul nostru, Care a pătimit $<\ldots>>103$ [Deci,] Te rugăm, preamilostive Părinte, să fie slujirea aceasta chemare [vrednică] a Numelui Tău şi adumbrire a Sfântului Tău Duh peste toată făptura... (continuarea nu s-a păstrat).

b) În Canonul Roman [„,Memento etsiam - pro defunctis”] ${ }^{104}$ :

„Adu-Ţi aminte, Doamne, şi de robii $(\mathrm{N})$ şi roabele $(\mathrm{N})$ care ne-au precedat cu semnul credinţei şi dorm în somnul păcii. Lor şi tuturor celor ce se odihnesc în Hristos Te rugăm să le dai loc de răcoare, de lumină şi de pace; prin Hristos Domnul nostru".

c) Missa (votiva) omnimoda ${ }^{105}$ - o liturghie apuseană săvârşită cu ocazia unor cereri speciale, are (în mod clasic pentru ritul apusean) două momente de pomenire a celor adormiţi: la offertorium (înainte de anafora) şi la intercessio, care este extraanaforal, plasat între „Tatăl nostru” şi immixtio (punerea Sf. Trup în potir).

La offertorium [Nomina offerentium]: „...Dă odihnă veşnică robilor Tăi $(\mathrm{NN})$ şi tuturor credincioşilor adormiţi ca, sălăşluiţi în sânul lui Avraam, să scape de pedepsele iadului; și-i învrednicește, ca la ceasul învierii, să se alăture corului Îngerilor" $" 106$.

La intercessio [embolism]: „Dă, Doamne, odihnă veşnică sufletelor robilor Tăi $(\mathrm{N})$ şi roabelor Tale $(\mathrm{N})$, şi tuturor celor adormiţi, care ne-au precedat $\mathrm{prin} / \mathrm{cu}$ semnul credinţei şi odihnesc acum somnul de pace; a căror trupuri

103 Probabil aici era partea de anamnesis şi institutio, după care urmează epicleza (din care s-a păstrat doar începutul) şi doxologia finală (care nu s-a păstrat). Dacă într-adevăr este vorba despre o veche anafora, posibila lipsă a Sanctusului nu ar trebui să ne uimească, chiar dacă acest element devine stabil pentru toate anaforalele din sec. IV şi mai departe.

104 CO1, p. 908, corectat după: $A L$ §4606, p. 1295. Acelaşi text îl avem şi în Sacramentariul lui Gelasie (CVL, p. 712) şi în cel al lui Grigorie cel Mare (CVL, p. 736).

${ }^{105}$ AL $\$ 5306-5351$, pp. 1479-1486.

${ }^{106} A L \S 5315$, p. 1481. 
zac aici sau în alte locuri, a căror suflete le-ai trimis la lumină, a căror nume au fost pomenite de noi în faţa acestui altar sau pentru care primim milostenie ca să ne rugăm pentru ei. Lor, Doamne, şi tuturor celor care odihnesc în Hristos, Te rugăm să le ierţi fărădelegile şi să le rânduieşti locul răcoros, în lumină şi pace"107.

d) În vechea Liturghie galo-hispanică, numită şi gotică ${ }^{108}$, avem următorul intercessio pre-anaforal ,post nomina”, adică după diptice:

„Cu sfinţenia Ta, Atotputernice, Dumnezeule, învrednicindu-ne să slujim cele rânduite de Tine, binevoieşte a primi cele aduse şi, cu îngăduinţă, dăruieştene cele cerute. Slăvita biruinţă a sfinţilor Tăi (lat.: sanctorum tuorum gloriosa merita ${ }^{109}$ să ne ocrotească, ca să nu cădem sub osândă; sufletele credincioşilor adormiţi, care se îndulcesc de fericire, să ne ajute nouă. Prin rugăciunile Bisericii dăruieşte de mângâiere celor care au nevoie, iar prinoasele celor ale căror nume se pomenesc înaintea altarului/jertfelnicului Tău, să fie bineprimite în ochii Tăi, ca să primească şi bunătăţile viitoare cu îmbelşugare, prin Domnul nostru..."

Apoi la immixtio (când pune părticica de Sf. Trup în potir), se spune formula quasi-comună în Apus: „Sfintele sfinţilor şi împărtăşirea cu Trupul Domnului nostru Iisus Hristos să fie celor ce primim şi bem, spre iertarea păcatelor, iar credincioşilor adormiţi - spre odihnă”.

107 AL $\$ 5323$, p. 1484.

108 Franz Joseph Mone, Lateinische und griechische Messen aus dem zweiten bis sechsten Jahrhundert, Frankfurt am Main, Verlag von Carl Bernhard Lizius, 1850 , p. 22; CVL, pp. 572-573. Această Liturghie nu trebuie confundată cu aşa-numita „Liturghie mozarabă”, care are mai multe influenţe din partea ritului roman; vezi: A. ORTIZ (ed.) Missale mixtum secundum regulam beati Isidori dictum Mozarabes, Toledo, 1500, precum şi ediţiile ulterioare din 1755, 1804 şi 1863 , traduse în $A L$, pp. 1758-1764, dar care nu reprezintă prea mult interes pentru subiectul nostru.

109 Am înlocuit cuvântul „,merit” cu „,biruinţă”, pentru a nu da impresia că la acea vreme deja exista ,teoria meritelor prisositoare” din scolastica medievală târzie. 
e) Nu putem să nu amintim şi de Liturghia Sf. Apostol Petru, care este varianta greacă bizantinizată a vechii liturghii romane, folosită în Sudul Italiei, iar după părerea unora, şi în Moravia, ca primă liturghie a slavilor ${ }^{110}$. În toată Liturghia nu există nici un fel de comemorare a celor adormiţi decât în prima „Rugăciune din spatele amvonului" (nu şi în cea alternativă). Prima parte a rugăciunii este o mijlocire pentru cei adormiţi, iar a doua pentru cei vii. Iată textul acestei mijlociri:

„Stăpâne Doamne, Dumnezeule Atotţiitorule, Care nu Te desparţi de robii Tăi şi nu treci cu vederea pe cei ce se roagă Ţie, odihneşte sufletele robilor Tăi - a tuturor ortodocşilor creştini - în desfătarea raiului, în locul de odihnă al celor binecredincioşi/evlavioşi, iertându-le lor greșelile făcute cu ştiinţă şi cu neştiinţă, şi învrednicindu-i de dulceaţa cea mai înainte făgăduită..."111

f) În Liturghia Sf. Ambrozie de Milan, în rugăciunea de la Offertorium sunt pomeniţi doar ,toţi creştinii, vii şi adormiţi, care aşteaptă mila Ta"112, iar în Anafora, întâlnim o cerere mai extinsă, plasată după epicleză, în comparaţie cu mijlocirea pentru cei vii şi pomenirea sfinţilor, care sunt plasate între Sanctus şi cuvintele de instituire $^{113}$. Iată textul acestei ,commemoratio pro defunctis”:

„Adu-Ţi aminte, Doamne, şi de robii Tăi (N) şi roabele Tale $(N)$, care ne-au precedat în credinţă şi odihnesc în somnul păcii. Lor, Doamne, şi tuturor celor adormiţi în Hristos, dă-le loc de odihnă, lumină şi pace; noi Te rugăm să Te milostiveşti [de ei] prin Acelaşi Hristos, Domnul nostru. Amin" 114 .

110 James R. CAMPBell, A Brief Introduction to the Liturgy of St. Peter, Woodstock, Illinois 1999; Михаил ЖЕЛтов, „Литургия апостола Петра”, în Православная Энщиклопедия, vol. 41, pp. 260-264.

111 J. CAMPBELL, A brief Introduction... p. 37.

112 Sorin-Dan Damian, Liturghia Sf. Ier. Ambrozie, episcopul Mediolanului, București, Edit. Galaxia Gutemberg, 2011, p. 55/81.

113 Ibidem, pp. 59-60, 86-87.

${ }^{114}$ Ibidem, p. 62, 91. 
g) În Liturghia celtică ${ }^{115}$, influenţată de contribuţia papei Gelasiu, cei adormiţi sunt menţionaţi printr-o formulă generală la sfârşitul dipticelor ("pentru odihhna celor adormiţi”), apoi într-o cerere mai extinsă la sfârşitul anaforalei:

„....întru pomenirea cinstiţilor patriarhi, proroci, apostoli, martiri şi a tuturor sfinţilor, care se roagă pentru noi Domnului Dumnezeu; pentru... [în Missalul lui Stowe urmează un şir de 120 de nume] şi pentru toţi cei ce au adormit şi ne-au precedat în pacea Domnului, de la Abel şi până astăzi, ale căror nume (numai) Dumnezeu le ştie şi le recunoaşte" 116 .

h) În Liturghia Sf. Gherman al Parisului ${ }^{117}$, la intercessio, printre cererile pentru vii, avem doar expresia scurtă „,ă odihnă celor adormiţi!". În schimb, la offertorium, avem nişte pomeniri şi rugăciuni mai extinse:

Preotul (tămâind): Pomenim şi sufletele robilor lui Dumnezeu $(\mathrm{N})$, care au adormit în pace.

Poporul: Şi pe toţi cei adormiţi în pace!

Preotul rosteşte rugăciunea: Doamne, Iisuse Hristoase, Dumnezeule Atotputernice, primeşte jertfa de laudă adusă de noi Ţie în această zi şi fii milostiv către cei vii, iar celor morţi le dă odihnă veşnică. Porunceşte ca numele lor, rostite de noi înaintea Ta, să fie scrise în veşnicie; căci Tu eşti Mântuitorul tuturor, care viezi şi împărăţeşti cu împreună-veşnicul Tău Părinte şi cu Sfầntul Duh, în vecii vecilor. Amin.

În concluzia acestei secţiuni, observăm că:

1) Mijlocirile şi pomenirile pentru cei adormiţi se regăsesc în majoritatea absolută a anaforalelor vechi şi noi, chiar dacă în

${ }^{115} A L, \S 6815-6837$, pp. 1751-1753.

${ }^{116} \mathrm{AL}, \S 6832$, p. 1753.

117 The Divine Liturgy of Saint Germanus of Paris, New York, The Saint Venantius Press, 1996. 
momente şi forme diferite, uneori distincte, iar alte amestecate printre comemorările de sfinţi sau mijlocirile pentru cei vii;

2) Cine sunt pomeniţi? Din textele de mai sus vedem că rugăciunile sunt aduse ,,pentru cei care... ”:

-au adormit (şi care s-au [de]săvârşit) întru dreapta credinţă,

-au adormit întru nădejdea învierii şi a vieţii veşnice,

-au bineplăcut lui Dumnezeu (din veac),

-au adormit de la (dreptul) Abel şi până astăzi,

-ne-au precedat în credinţă,

-s-au îmbrăcat în Hristos prin Botez şi L-au primit de la Sfântul Jertfelnic,

-au mâncat Trupul şi au băut Sângele Lui,

- a căror trupuri zac [îngropate] aici şi pretutindeni,

-ne-au cerut să ne rugăm pentru ei,

-pentru care s-a dat milostenie şi se aduce tămâie,

-îi ştim şi nu-i ştim [după nume], pe care $i$-am pomenit şi pe care nu i-am pomenit (clerici, ctitori, împăraţi, laici etc.)

-pentru toți fraţii noştri întru Hristos (căci nimeni nu este fără de păcat, în afară de Dumnezeu).

\section{3) Ce se cere pentru cei adormiţi?}

-odihnă sufletelor şi trupurilor, -sălăşluire în sânurile lui Avraam, (Isaac şi Iacov) $)^{118}$, -sălăşluire în loc de verdeaţă, la apa odihnei, în raiul desfătării, de unde a fugit durerea, intristarea şi suspinul, -sălăşluire în locaşul/strălucirea sfinţilor, în slava dumnezeiască şi în pământul celor vii,

${ }^{118}$ La Pseudo-Dionisie Areopagitul întâlnim tâlcuirea „sânurilor lui Avraam” expresie care, aşa cum am văzut deja, se întâlnește în majoritatea rugăciunilor pentru adormiţi: „....sânurile [lui Avraam - Lc. 17, 23] sunt, după socotinţa mea, stările preadumnezeiești și binecuvântate ale fericiţilor patriarhi și ale tuturor celorlalţi sfinţi care bineprimesc lângă ei pe toţi cei asemenea cu Dumnezeu în veșnica și preafericita lor desăvârşire" (cf. Despre ierarhia bisericească, VII, 5). Vezi şi: Jérôme BASCHET, Le Sein du père Abraham et la paternité dans l'Occident médiéval, Paris, Gallimard, 2000. 
-numărarea/moştenire cu sfinţii, sfinţirea sufletelor,

-ridicare în Ierusalimul ceresc,

-şederea de-a dreapta în Ziua [arătării] Domnului,

-lumină şi pace,

-lăsarea greşelilor, iertarea păcatelor, ispăşirea datoriilor,

-izbăvire de osânda cea viitoare şi de pedepsele iadului,

- ca Dumnezeu să nu intre la judecată cu robii Săi (căci

nimeni din cei vii nu-i drept înaintea $\mathrm{Sa}$ ),

-învierea din morţi şi alăturarea la ceata/corul îngerilor,

- viaţa cea nouă în Împărăţia Cerurilor, unde străluceşte

lumina feţei lui Dumnezeu,

-bunătătile pe care „ochiul nu le-a văzut, urechea nu le-a auzit şi la inima omului nu s-au suit" şi pe cele ,pregătite celor ce-L iubesc pe Domnul” / Sfânt Numele Lui.

4) Deşi Liturghiile bizantine au suferit şi schimbări destul de târzii (sec. XI-XIV), care ar fi permis o îmbogăţire (firească şi neobservabilă) a mijlocirilor pentru cei adormiţi, totuşi, spre deosebire de celelalte liturghii orientale şi chiar occidentale, mijlocirile pentru cei adormiţi din VAS şi CHR sunt cele mai scurte şi mai sărace. Aceasta se datorează faptului că majoritatea pomenirilor nominale au emigrat spre prothesis (sec. XI-XII), dar şi faptului că, deja în momentul în care VAS (apoi şi CHR) au preluat expresia din IAC: „şi-i odihneşte unde străluceşte lumina feţei Tale" (sec. VIII), teologia bizantină, influențată de imnografia funerară a Sf. Ioan Damaschin († 749), care, aşa cum observa A. Schmemann $^{119}$, M. Arranz ${ }^{120}$ şi E. Velkovska ${ }^{121}$, nu mai avea tematica pozitivă şi plină de nădejde a vechilor rugăciuni, ci a adoptat pedagogia fatalistă a cărţilor sapiențiale ale Vechiului

119 Cf. Liturghia morţii şi cultura contemporană (rus) /Литургия смерти и современная культура, Moscova 2013, pp. 109-110, 114. Vezi şi Paul J. FENwICK, „Death and Dying in Byzantine Liturgical Traditions”, în Eastern Churches Review, 8.2/1976, pp. 152-161.

${ }^{120}$ Cf. Избраннье сочинения по Литургике, Том 2 - Таинства Византийской Традиции, Рим-Москва, Институт Философии, Теологии и Истории Св. Фомы, 2003, pp. 640-641.

${ }^{121}$ E. Velkovska, Funeral Rites..., p. 46. 
Testament $^{122}$. Poezia şi oratoria acelor secole, indiferent cât de frumoasă şi dramatică ar părea, nu mai era concepută ca o rugăciune adresată lui Dumnezeu pentru odihna celor adormiţi, ci, mai degrabă, ca o cateheză despre iminența morții, urâciunea stricăciunii şi putrezirii, inutilitatea agonisirii de bogăţii sau a orgoliului de a aparţine unei clase sociale superioare etc. sau, în cel mai bun caz, eliberarea de legile fizice ale acestei lumi. ${ }^{123}$ Prin urmare, în timpul definitivării formei actuale de intercessio pentru VAS şi CHR, dar şi a stabilirii rânduielii prothesis-ului, „moda” imnografică a timpului era axată pe alte subiecte, care nu aveau cum să intre în Liturghia bizantină, ci au rămas doar pentru slujbele de înmormântare sau pentru alte tipuri de pomeniri.

5) În prezent, cel puţin în cazul CHR, unde intercessio (inclusiv pentru vii) este destul de scurt, iar cântarea Axionului este, de cele mai multe ori, destul de lungă, s-ar putea ca cererea de mijlocire generală pentru cei adormiţi, care oricum a suferit cel puţin două completări de-a lungul timpului (vide supra), să fie îmbogăţită cu idei din alte anaforale sau liturghii orientale ${ }^{124}$, care să se încadreze în tematica pozitivă a mijlocirilor pentru cei

122 А. НикифоровА, „Гимнография смерти: лоно Авраама или "мрачный реализм"?", referat nepublicat, susținut la o Conferinţă a Univ. Sf. Tihon din Moscova, 15-19 aprilie 2019 şi oferit cu amabilitate de autoare pentru uzul personal. Vezi: Christodoulos, pp. 217-256; М. ДАШЕВСКАЯ, Ю. А. ШтондА, Возникновение и развитие чинопоследования христианского погребения в Византии в X-ХІІ веках, în Вестник Свято-Филаретовского Института, 24/2017, pp. 46-60.

${ }^{123}$ A se vedea şi studiul lui Stelyios Muksuris, ,Revisiting the Orthodox Funeral Service: Resurrecting a Positive Thematology in the Rite for the Dead", paper presented at the International Conference on Liturgical Renewal, held at Hellenic College and HolyCross Greek Orthodox School of Theology, Brookline, MA, from March 15-16, 2013.

124 Despre posibilitatea şi chiar necesitatea înnoirii liturgice prin revizuirea cărţilor de

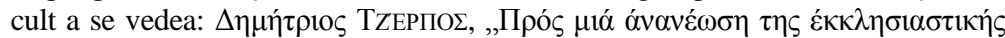

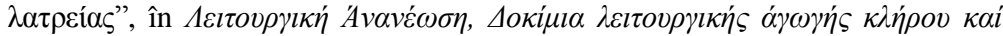

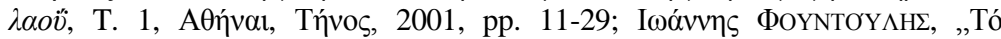

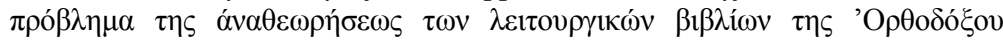

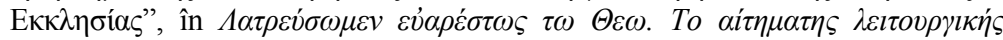

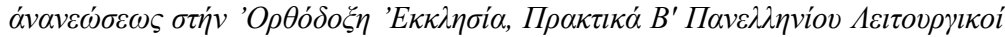

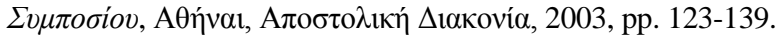


adormiţi, făcute înaintea Sfintei Jertfe. O astfel de îmbogăţire nu trebuie să enumere cât mai multe categorii ale celor adormiţi sau diferite grade de rudenii, aşa cum se face de obicei în Biserica Ortodoxă Română ${ }^{125}$, ci să recupereze, atât cât este posibil, duhul eshatologic conservat mai bine în alte liturghii.

O posibilă variantă a acestei cereri de mijlocire pentru cei adormiţi ar putea fi: , Şi pomeneşte [Doamne, pe robii Tăi $(N)^{126}$ şi] pe toţi cei mai dinainte adormiţi întru nădejdea învierii şi a vieţii veşnice: părinţi şi fraţi ai noştri, şi pe toţi pe care mai înainte i-am pomenit şi pe care, din neștiință sau pentru mulţimea numelor, nu i-am pomenit; iartă-le lor toate greşelile cele de voie şi cele fără de voie, sălășluiește$i$ în sânurile lui Avraam şi în locaşurile drepților, şi-i odihneşte unde străluceşte lumina feţei Tale”. După cum se poate observa, adaosurile sunt destul de scurte, dar suficient de grăitoare şi se înscriu foarte bine în tematica şi limbajul general al ambelor anaforale bizantine ${ }^{127}$.

\section{Pomenirea celor adormiţi la prothesis}

În zilele noastre, când vorbim despre pomenirea celor adormiţi la Dumnezeiasca Liturghie, avem în vedere, în primul rând, pomenirile de la prothesis (proscomidie) şi scoaterea de miride pentru cei adormiți din a cincea prescură ${ }^{128}$, dar astfel de pomeniri nu erau cunoscute în primul mileniu şi, chiar după apariţia lor, practica şi sensul scoaterii lor nu a fost întotdeauna aceleași.

\footnotetext{
125 Vezi marea rugăciune de pomenire a celor adormiţi în cadrul prothesisului, întâlnită doar în Liturghierul românesc (Liturghier, pp. 125-126; vezi şi LOIA, pp. 87 şi 216) şi pomenirile de la Intrarea Mare (Liturghier, p. 163-164; LOIA, p. 116).

126 Aici ar putea fi pomeniţi cei mai importanţi ctitori adormiţi, precum şi persoanele pentru care se fac pomeniri speciale sau care sunt recent adormiţi (până la 40 de zile), dar nu prea multe nume.

127 Aşa cum demonstrează foarte clar S. Parenti, mai ales în sec. VIII-XIII textele celor două anaforale bizantine au suferit mai multe influenţe şi asimilări reciproce (aşa numitul Angleichung), precum şi anumite influenţe exterioare, în special din IAC. Poate că acest proces ar fi continuat şi mai târziu, dacă nu apărea tiparul care a fixat variantele textuale de atunci; (cf. PARENTI, pp. 307-440).

${ }^{128}$ Despre practica actuală vezi Liturghier, pp. 122-127. A se vedea şi varianta din $L M$, pp. 53-56.
} 
Spre deosebire de acel offerentium commemoratio din ritul apusean, cunoscut cel puţin din sec. IV încoace, primele mărturii despre pomenirile celor vii şi adormiţi la prothesis apar abia începând cu sec. XI şi se generalizează abia în sec. XIV ${ }^{129}$, iar practica scoaterii de miride pentru vii şi adormiţi, dincolo de interpretările pietiste foarte noi şi intens popularizate, nu are nici un argument patristic, liturgic sau dogmatic clar şi indubitabil. Chiar şi discuţiile din sec. XIII-XV privind miridele de la prothesis se limitează fie la descrierea practicii aflate în uz, fie la întrebarea despre „(ne)prefacerea” acestora în Sfântul Trup, dar nu şi la necesitatea sau ,efectul" scoaterii de miride. Interpretarea mai târzie a Sf. Simeon al Tesalonicului ( $† 1429)$, dar mai ales introducerea, în sec. XVII, a cuvintelor: „Spală, Doamne, păcatele celor ce s-au pomenit aici, cu Scump Sângele Tău [pentru rugăciunile sfinţilor Tăi]", la momentul punerii lor în potir, chiar dacă par interesante, ridică întrebări teologice foarte serioase, care încă nu şi-au găsit explicaţii unanim acceptate ${ }^{130}$. Pe lângă implicațiile teologice deloc neglijabile, observăm că însăși rânduielile liturgice mai vechi nu dădeau o valoare prea mare pomenirilor de la prothesis întrucât, cel puţin până în sec. IX-X, întreg prothesis-ul era săvârşit de către diacon ${ }^{131}$, ceea ce îl lipsea, în mod automat, de prea multe implicaţii sacramentale, apoi (sec. XI-XIII) doar agneţul era scos de către preot şi miridele continuau să fie scoase de către diacon; deja în sec. XIV-XVII scoteau miride şi preotul şi diaconul ca, în cele din urmă, totul să facă doar preotul, dând o altă greutate teologică fiecărui gest ${ }^{132}$.

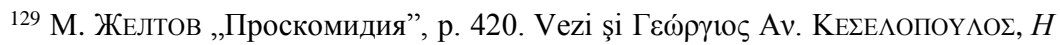

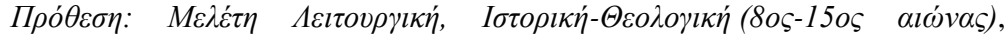

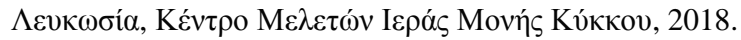

${ }^{130}$ Ioannis Foundoulis, Dialoguri liturgice, vol. V, trad. Sabin Preda, București, Edit. Bizantină, 2011, pp. 323-325.

${ }^{131}$ Cf. Nicolae al Andidei, ICLB, p. 292.

132 Marco MANDALÀ, La protesi della liturgia nel rito bizantino-greco, Grottaferrata, Scuola tipografica italo-orientale S. Nilo, 1935, pp. 107-147. Сергей Муретов, „Чин проскомидии в греческой Церкви с XII до половины XIV века", în Чтения в Обществе любителей духовного просвещения, Москва, 1894, pp. 247-257. 
Rânduiala actuală, a căror rădăcini poate fi urmărită până prin sec. XI-XII, prevede ca din prescura a IV-a să se scoată o miridă (mai târziu - mai multe) pentru ierarhie, conducători şi pentru toţi cei vii, iar din prescura a V-a pentru ctitori şi toţi cei adormiţi. Aşa cum ne arată vechile diataxe, singura miridă triunghiulară era cea pentru Maica Domnului, apoi, cu timpul, şi cea pentru sfinţi (una comună pentru toate cetele), dar nu existau miride de forme speciale pentru ierarh, conducători sau ctitori, şi nici indicaţia de a separa miridele pentru cei vii şi adormiţi ${ }^{133}$, ci toate miridele erau la fel şi se puneau împreună, doar că, tot mai des, erau scoase din prescuri diferite ${ }^{134}$. Mai mult decât atât, până în sec. XV şi sporadic şi după aceea, se credea că toate miridele, asemenea agneţului, se prefac în Sf. Trup şi din ele ne putem împărtăşi ${ }^{135}$.

Momentul de cotitură în această problemă 1-a constituit exegeza liturgică a Sf. Simeon al Tesalonicului (†1429), care spunea clar că miridele pentru sfinţi, vii sau adormiţi nu se prefac nici în Trupul lui Hristos şi nici în trupurile celor pomeniţi, ci doar se împărtăşesc din sfinţenia lui Hristos (prin atingere, nu prin rugăciune!) şi, din acest motiv, din miride nu ne putem împărtăşi ${ }^{136}$. Totuşi, aserţunea lui Simeon al Tesalonicului, cel puţin în sec. XVXVI, nu era considerată satisfăcătoare, mai ales că oponenţii lui,

${ }^{133}$ Ediţia recentă a Liturghierului Vatopedin propune revenirea la doar patru-cinci miride: una triunghiulară pentru Maica Domnului, una rotundă (comună) pentru cetele de sfinţi şi câte una pentru vii şi adormiţi ( + cea pentru preotul celebrant); vezi $B \Theta \Lambda$, pp. 14-17; $\Sigma \Sigma \Theta \Lambda$, pp. 69-73.

134 Cf. Николай Фомич КРАСНОСЕЛЬЦЕВ, Материаль для истории чинопоследования литургии св. Иоанна Златоустого: Уставы патриарха Константинопольского Филофея и протонотария Великой иеркви Димитрия Гемиста по рукописям XIV в., Казань, Тип. Имп. ун-та, 1895, pp. 20-21, 44-46; Michael Zheltov, „A Slavonic Translation of the Eucharistic Diataxis of Philotheos Kokkinos from a Lost Manuscript (Athos Agiou Pavlou 149)", în Daniel GALADZA et alii, TOXOTHS: Studi per Stefano Parenti, col. „Analekta Kryptoferres”, 9, Grottaferrata, 2010, pp. 356-358; Diataxis Vatopedina, pp. 43, 60-61.

135 QARAMAH, pp. 7-9; М. АсмУС, „К вопросу об освящении поминальных частиц за Божественной Литургии", în Вестник ПСТГУ, 14/2005, pp. 5-22.

${ }^{136}$ Cf. Erminia $\$ 102-103$, în ICLB, pp. 399-340 şi Dialog $\$ 94+$ excurs, în ICLB, pp. 418-423. 
calificați de regulă ca ,latino-cugetători"137, aveau argumente istorice şi liturgice mult mai credibile ${ }^{138}$, iar cel mai important argument era cel al unităţii/unicităţii pâinii euharistice, a căror fărimituri suntem noi, membrii Bisericii, înfăţişându-ne înaintea lui Dumnezeu ca o singură pâine, care în întregime se preface în Trupul lui Hristos (cf. 1 Cor. 10, 17; Didahia IX) ${ }^{139}$.

137 În sec. XIII ideea prefacerii miridelor era susţină şi de patriarhul uniat Ioan Becos al Constantinopolului (1275-1282). Cu această pretenţie, ca fiind singura care justifică scoaterea de miride (sic!), au venit latinii şi la şedinţa din 6 iulie 1439 a Sinodului de la Ferrara-Florența; vezi Joseph GILL (ed.), Concilium Florentinum: Documenta et scripta - Ser. B, vol. 5, fasc. 2, Roma, Pontificium Institutum Orientalium Studiorum, 1953, pt. 2, p. 468). Ştim că apusenii aveau pretenţii privind ritul proscomidiei încă din sec. XI, când cardinalul Humbert lăuda practica de la Ierusalim (legată de IAC) de a nu extrage agneţul din pâine, condamnând practica bizantină (cf. BRIGHTMAN, p. 540.7). Se pare că pe la 1054 la Constantinopol încă nu se scoteau miride, căci aceasta ar fi fost un cap de acuzare în plus; vezi şi Stéphane VeRHELST, „L'introduction et la disparition du rite de Prothèse dans la Liturgie de Jérusalem", în Studia Christiana Orientalia. Collectanea, 31/1998, p. 31.

138 În sprijinul acelor argumente veneau şi unele variante ale comentariilor lui Gherman al Constantinopolului şi ale lui Nicolae/Theodor al Andidelor; vezi QARAMAH, pp. 9-10.

${ }^{139}$ Despre aceasta vezi şi LOIA, p. 69-72. O critică interesantă a acestui rit bizantin întâlnim la cardinalul Nil Borgia: „De mai multe secole ne-a fost pregătit un rit special, complicat, plin de simboluri și de ceremonial, o adevărată exuberanță bizantină: s-a creat chiar și o slujbă [aparte] - liturghia proscomidiei, pe care orice liturgist se crede dator în mod onest să o pună pe primul loc în enumerarea pragmatică: liturghia proscomidiei, liturghia catehumenilor, liturghia credincioșilor. Însă în antichitate nu exista nimic din toate acestea: se lua (în acele vremuri) pâine, vin și apă, şi ajungea o simplă binecuvântare pentru a o distinge de restul [pâinii]; cu un cuțit modest se desprindea partea necesară...; cât despre formula antică a binecuvântării, nimic mai simplu și mai armonios: i se cerea lui Dumnezeu să binecuvânteze acele elemente și să primească tainele în altarul Său ceresc; astăzi, însă, este pus în mișcare întregul rai al fericiților: îngerii cu ierarhiile lor, Botezătorul, Apostolii etc., o adevărată ardoare bizantină a celor mai înfloritoare timpuri care, în fond și la urma urmei, sfârșește prin a se dovedi inutilă chiar şi pentru ei înșiși, pentru că părticelele cu care se umple discul prin toate pomenirile nu sunt consacrate de către ei și rămân ceea ce erau! Însă, dintr-o asemenea incoerență interpretativă, rezultă şi un bine: inutilitatea atâtor adăugiri și consfințirea proscomidiei primare, care se desfasşura asupra unei singure pâini"; (apud M. MANDALÁ, La protesi..., pp. 107-108). 
Problema miridelor se reia în sec. XVII prin mitropolitul Petru Movilă, dar a fost privită cu suspiciune de către patriarhul Nikon al Moscovei, în primul rând pentru că era promovată la pachet cu teoria latină despre prefacerea euharistică la momentul rostirii cuvintelor de instituire (deşi între cele două idei nu există neapărat o legătură). După anumite consultări cu patriarhul Paisie I al Constantinopolului, ruşii au respins ideea prefacerii miridelor şi practica împărtăşirii din ele ca fiind eretice ${ }^{140}$. Mai mult decât atât, contrar diataxelor de până atunci, Slujebnikul rus a reglementat ca miridele să fie puse în potir abia după împărtăşirea laicilor, iar cuvintele „Spală, Doamne...”, sugerate chiar de patriarhul Paisie ${ }^{141}$, veneau să precizeze, în primul rând, sensul reprezentativ-simbolic al miridelor. Deci, introducerea acestei formule abia după împărtăşirea laicilor şi atribuirea ei diaconului, arată clar că, iniţial, aceasta nu a fost prevăzută ca o formulă sacramentală. $\mathrm{Cu}$ toate acestea, deja în sec. XVIII, toate pomenirile de la prothesis sunt privite exclusiv prin prisma acestei formule, ceea ce în mod clar este o exagerare şi o forţare. $\mathrm{O}$ modalitate de a readuce această idee în aria vechilor interpretări ar fi să vedem în această formulă nu o cerere imperativă, care se realizează efectiv în momentul punerii miridelor în potir, ci să-i dăm o interpretare retrospectivă, centrată pe anafora şi, în special, pe mijlocirile care se fac după epicleză singurul moment care, aşa cum precizează Sf. Nicolae Cabasila ${ }^{142}$, reprezintă cu adevărat ,celebrarea Jertfei mântuitoare a Mielului lui Dumnezeu” şi, implicit, „spălarea păcatelor”.

Mai mult decât atât, împărtăşirea din aceste roade ale jertfei nu poate avea loc decât bând din Sfântul Lui Sânge, aşa cum a rânduit Însuşi Mântuitorul Hristos zicând: ,Beţi dintru acesta toţi!

140 М. БЕРНАЦКИЙ, „Освящение поминальных частиц в контексте спора о времени пресуществления Святых Даров, состоявшегося в посл. четв. XVII в. в Москве”, în Вестник ПСТГУ 16/2006, pp. 129-144.

141 Vezi textul extins la I. Foundoulis, Dialoguri..., vol. 5, §529, p. 112. De remarcat că înşişi grecii nu au avut niciodată această formulă în Ieratikon, decât în ediţia din 1977, care însă repede a fost retrasă din cauza mai multor inovaţii străine de tradiţia liturgică greacă, printre care şi formula ,Spală, Doamne, păcatele...".

${ }^{142}$ Sf. Nicolae Cabasila, Erminia II:9, în ICLB, p. 342. 
Acesta este Sângele Meu, al Noului Legământ, care pentru mulţi se varsă spre iertarea păcatelor" (Mt. 26, 27-28). Hristos nu ne-a spălat păcatele stropindu-ne cu Sângele Său pe dinafară, aşa cum se întâmpla în Vechiul Testament şi cum, mult prea plastic, înţelegea şi patriarhul Paisie I al Constantinopolului ${ }^{143}$, ci singura spălare de păcate se poate face numai pe dinăuntru, sfinţindu-ne prin împărtăşirea „,cu frică de Dumnezeu, cu credinţă şi cu dragoste” din Trupul Lui şi Sângele Lui. Acesta este şi scopul Liturghiei ${ }^{144}$, iar deplasarea accentului de pe împărtăşirea euharistică pe pomeniri, indiferent ce tâlcuire şi greutate li se dă acestora, înseamnă, de fapt, şi o abatere de la scop sau chiar ratarea lui.

Să nu uităm nici faptul că, iniţial, miridele scoase în prezent din cele patru prescuri sunt, de fapt, urme ale practicii mai vechi de a scoate cinci agneţe întregi, uneori chiar pe cinci discuri diferite ${ }^{145}$. Prin urmare, miridele scoase cu ocazia sărbătorii unui sfânt sau pentru a pomeni pe cineva dintre vii sau adormiţi, erau iniţial agneţe scoase din prescurile oferite de credincioşi, iar ofranda în sine se aducea în perspectiva sfinţirii euharistice şi împărtăşirii din ea. Până în sec. XV nu a existat nici un fel de interpretare eclesiologică a scoaterii de miride şi a punerii lor lângă agneţ, pentru că singura formă liturgică de manifestare a ecclesiei era împărtăşirea membrilor ei dintr-un singur potir, aşa cum spunem şi în VAS, imediat după epliceză: „,iar pe noi, pe toţi, care ne împărtăşim dintr-o pâine şi dintr-un potir, să ne uneşti unul cu altul spre părtăşia Aceluiaşi Sfânt Duh...”.

143 „Gândul Bisericii noastre, cu care pune miridele oamenilor în potir, este acela de a spăla păcatele celor pomeniţi cu Cinstitul Sânge al Stăpânului; şi este ca şi cum ar fi făcut (de pildă) Ioan, [ucenicul iubit al Domnului,] aducând lângă crucea lui Hristos pe un oarecare păcătos, ca să îl pună sub rănile lui Iisus, unde curgea Sângele, ca să îl spele cu Acesta; pentru că atunci omul acela nu ar deveni Hristos după fire, ci numai curăţit şi spălat de păcate prin Sângele lui Hristos..." (apud I. Foundoulis, Dialoguri..., vol. 5, §529, p. 112). După cum vedem, această interpretare nu implică credinţa sau pocăinţa celui păcătos şi nici împărtăşirea euharistică, ci doar un fel de „spălare mecanică” a păcatelor prin simpla pomenire şi turnare a miridelor (care 1-ar reprezenta chiar pe cel pomenit) în Sfântul Sânge.

${ }^{144}$ Sf. Nicolae Cabasila, Erminia III:1, în ICLB, p. 344.

${ }^{145}$ LOIA, pp. 67-72; $\Sigma \Sigma \Theta \Lambda$, pp. 69-73. 


\section{Concluzii}

În concluzie, constatăm că, în ritul bizantin (nu la fel şi în alte tradiţii liturgice):

a) Pomenirile nominale ale celor vii şi adormiţi, care până spre sfârşitul sec. XI făceau parte din repertoriul diaconal al anaforalelor, au emigrat încet spre prothesis. Această emigrare nu poate fi observată din Evhologhii, unde se scriau, de regulă, doar rugăciunile preoţeşti, ci mai mult din Diataxe (sec. XI-XIV), care ne descriu atât primele forme ale prothesisului cu pomeniri, cât şi textele diaconale ale dipticelor, care tocmai erau pe cale de dispariţie $^{146}$;

b) Ca pomenirile de odinioară, legate exclusiv de anafora (indiferent că intercessio era înainte sau după epliceză), pomenirile arătau ,comuniunea cu Hristos a celor pomeniţiı" ${ }^{147}$, iar această comuniune, aşa cum o presupune şi termenul, se manifesta şi concretiza prin împărtăşirea euharistică. Nu putea fi pomenit vreun adormit care nu a fost în comuniune cu Hristos şi Biserica şi nici vreo persoană vie căzută sau dezinteresată de această comuniune. Lanţul de acţiuni: ${ }^{1)}$ aducerea darului de jertfă ${ }^{2)}$ pomenirea celui care a adus sau pentru care $s$-a adus ${ }^{3)} \hat{i m p a ̆ r t a ̆ s ̧ i r e a ~ e u h a r i s t i c a ̆ ~}$, toate implică doar persoane ce se află (sau s-au aflat în timpul vieţii până în clipa morții) în comuniune cu Hristos şi Biserica;

146 Există mai multe cauze ale acestor metamorfoze simultane şi interdependente: tradiţia monahală studită a impus slujirea zilnică a Liturghiei (a se vedea mai ales Tipicul Everghetinos), ceea ce a dus la o mai mare necesitate de preoţi şi o tot mai mare criză de diaconi, iar dispariţia diaconilor, cel puţin la liturghiile de peste săptămână, nu putea să nu ducă la deplasarea sau revizuirea unor elemente considerate până atunci strict diaconale. La acestea se adaugă faptul că, în aceeaşi perioadă, Liturghia s-a lungit destul de mult: antifoanele Liturghiei (enarxa) devine stabilă, iar prothesisul, lungit şi el de tot felul de pomeniri (pe care trebuia să le facă chiar preotul, neavând diacon), nu se mai putea săvârşi la enarxă, ci se deplasează ca element distinct înainte de Liturghia Cuvântului.

${ }^{147}$ Cf. Dionisie Areopagitul şi Nicolae Cabasila; vezi ICLB, p. 341. 
c) Cu timpul, din motive obiective şi subiective, şirul de acţiuni descris mai sus, care culmina în mod firesc şi obligatoriu cu împărtăşirea euharistică $\breve{a}^{148}$, a fost redus la primele două verigi ale lanţului (sau chiar numai la a doua), iar pomenirile, indiferent de forma şi locul lor în Liturghie ${ }^{149}$, au început să fie percepute ca un scop în sine şi eficiente per se. Mai mult decât atât, mai ales prin introducerea formulei „Spală, Doamne, păcatele celor ce s-au pomenit...” s-a creat impresia (vehiculată şi în mediile bisericeşti oficiale, inclusiv de către unii ierarhi) că pomenirea la prothesis (proscomidie) prin scoatere de miride şi apoi turnarea acestora în potir, ar ierta păcatele celor pomeniţi şi chiar ar scoate din iad sufletele celor adormiţi în păcate ${ }^{150}$, fără a menționa legătura cu împărtăşirea euharistică. Astfel, simpla aducere a jertfei (adică slujirea Liturghiei), care pentru Nicolae Cabasila nu era decât lucrare/instrument (É $\rho \gamma o v)$, în lipsa unui scop ( $\tau \dot{\prime} \lambda o \varsigma$ ) superior (adică „sfinţirea prin împărtăşire”), devine scop în sine, exact ca în scolastica tridentină, numai că sub masca ortodoxă a scoaterii de miride;

d) Având în vedere lipsa frecventă a diaconului (dar şi în cazul prezenţei acestuia) constatăm că dipticele diaconale de la anafora nu au cum să mai revină la locul de odinioară. $\mathrm{Cu}$ toate acestea, considerăm necesar ca în locul lor să se spună cel puţin partea concluzivă a vechilor diptice [,,Şi pe cei pe care fiecare $\hat{\imath} i$ are în cugetul său; şi pe toţi şi pe toate"], care poate fi rostită şi de preot, ca o continuare logică a mijlocirilor generale, dar care ar sublinia faptul că pomenirile se încheie şi se desăvârșesc anume în

${ }^{148} \mathrm{Nu}$ se puteau primi jertfe de la cei nebotezaţi sau excomunicaţi. Cauza era imposibiltatea lor de a se împărtăşi, iar nepomenirea lor era un efect al primei şi ultime cauze.

149 A se vedea şi procesul de evoluţie al pomenirilor de la Intrarea Mare (apărute chiar în sec. XII-XIII) şi interpretările care li s-au dat în timp (sec. XIV-XV); vezi Robert F. TAFT, O Istorie a Liturghiei Sfântului Ioan Gură-de-Aur, vol. II: Intrarea cea Mare, Cluj-Napoca, Edit. Renaşterea, 2012, pp. 314-320. În consecinţă, chiar şi imnul Heruvic, perceput iniţial ca imn pregătitor pentru împărtăşire (cel mai vechi imn la Intrarea Mare fiind chiar „Cinei Tale...”), a încetat să mai fie văzut astfel, pentru că nici împărtăşirea euharistică nu mai era văzută ca o condiţie şi o pecetluire a pomenirilor.

${ }^{150}$ Vide supra, nota 1. 
acest moment, şi că la ele trebuie să participe întreaga comunitate, fiecare având grija şi datoria de a se ruga pentru toţi pe care ,îi are în cugetul său" şi de a-i pomeni ,,pe toţi [bărbaţii credincioși] şi pe toate [femeile credincioase]". Este interesantă şi tradiţia (athonită) de a-i implica pe credincioşi la pomenirile de la prothesis când, înainte de a acoperi Cinstitele Daruri, preotul sună din clopoţel, slujba se întrerupe şi fiecare, preţ de câteva secunde, îşi pomeneşte viii şi morţii. Toate acestea ar tempera abordările magice precum că pomenirile se pot face şi în absenţa celui pomenit (sau măcar a unui reprezentant al familiei) şi că ar fi important că pentru fiecare nume să se scoată neapărat o părticică, care apoi să fie pusă în potir.

Pomenirile nominale, aşa cum s-a stabilit şi generalizat în ultimul mileniu, trebuie să rămână legate de prothesis, chiar dacă ele pot începe şi înainte de aceasta ${ }^{151}$ şi se pot termina mai târziu, fără a scoate neapărat câte $\mathrm{o}$ părticică pentru fiecare nume, căci mai important decât orice miridă, însuşi Agneţul este cel care se aduce şi se va jertfi pentru păcatele noastre. Totuşi, aceste pomeniri, care uneori sunt destul de multe şi nicidecum nu pot fi lăsate pentru intercessio, pot fi privite ca o anticipare a pomenirii rezumative ,,pentru toţi şi pentru toate" care se va face în faţa Sfintei Jertfe după eplicleză, înainte de împărtăşirea euharistică şi în legătură cu aceasta. Iar formula „Spală, Doamne..." prevăzută pentru momentul punerii miridelor, cred că ar trebui suprimată, revizuită sau, cel puţin, reinterpretată.

$\cos 80$

\section{Bibliografie selectivă}

1. $A L=$ DE LEÃo CoRDEIRO, José (ed.), Antologia Litúrgica: textos litúrgicos, patrísticos e canónicos do primeiro milénio, Fátima, 2015.

${ }^{151} \mathrm{Ne}$ referim la simplele pomeniri făcute de coliturghisitori în timpul Utreniei şi a Liturghiei Cuvântului. Nu considerăm corectă practica rusească de a pomeni încă de la Vecernie şi a scoate miride doar cu epitrahil şi mânecuţe, inclusiv de preoţi care a doua zi nu vor sluji. Scoaterea de miride este un act ce ţine de prothesis şi el trebuie făcut exclusiv de cei care deja s-au îmbrăcat în toate veşmintele şi vor sluji în acea zi. 
2. BAS = Liturghia/Anaforaua (greacă bizantină a) Sfântului Vasile cel Mare.

3. BERNATTKIY = БЕРНАЦКИЙ, Михаил, „Освящение поминальных частиц в контексте спора о времени пресуществления Святых Даров, состоявшегося в посл. четв. XVII в. в Москве”, în Вестник ПСТГУ, 16/2006, pp. 129-144.

4. BRIGHTMAN = BRIGHTMAN, Frank Edward, HAMMOND, Charles Edward, Liturgies: Eastern and Western, being the texts original or translated of the principal liturgies of the church, vol. 1: Eastern liturgies, Oxford 1896/1967.

5. COI = Diac. Ioan ICĂ jr. (ed.), Canonul Ortodoxiei, vol. 1, Sibiu, Edit. Deisis, 2008.

6. CHR = Liturghia/Anaforaua Sfântului Ioan Hrisostom (Gură-de-Aur).

7. Christodoulos $=$ CHRISTOdoulos, Themistoklis, L'ufficio funebre nei manoscritti greci dei secoli X-XII (gr.), Pontificium Institutum Orientale, Facultas Scientiarum Ecclesiaticarum Orientalium, 1996.

8. $C V L=$ БЕЛОУСов, Андрей Рэмович (ed.), Собрание древних литургий восточных и западных [Colecţia vechilor liturghii răsăritene şi apusene], Москва, ДАРЬ, 2007.

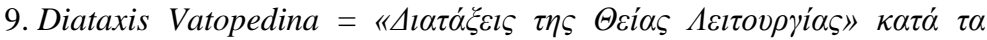

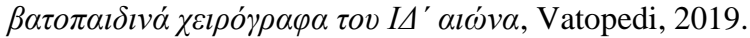

10. Dipticele $=$ TAFT, Robert F., $O$ istorie a Liturghiei Sfântului Ioan Gura de Aur, vol. IV: Dipticele, trad. Cezar Login, Cluj-Napoca, Edit. Renaşterea, 2009.

11. IAC = Liturghia/Anaforaua greacă a Sfântului Iacov.

12. ICLB = IC $\check{A}$, Ioan I. jr., Integrala comentariilor liturgice bizantine: de la Dionisie Areopagitul la Simeon al Tesalonicului, Sibiu, Edit. Deisis, 2011.

13. JoHnson $=$ Maxwell E. Johnson, The Prayers of Sarapion of Thmuis: A Literary, Liturgical, and Theological Analysis, col. „Orientalia Christiana Analecta”, 249, Roma, PIO, 1995.

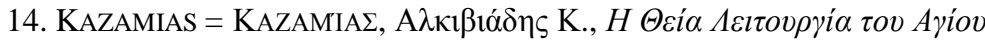

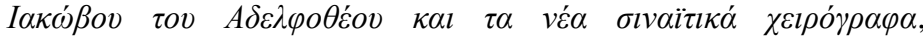

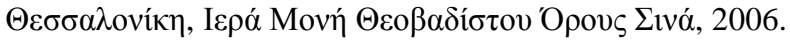

15. KRASNOSELȚEV = КРАСНОСЕЛЬЦЕВ, Николай Фомич, Материаль для истории чинопоследования литургии св. Иоанна Златоустого: Уставы патриарха Константинопольского Филофея и протонотария Великой иеркви Димитрия Гемиста по рукописям XIV в., Казань, Тип. Имп. ун-та, 1895.

16. Liturghier $=* * *$ Liturghier, București, Edit. Institutului Biblic și de Misiune Ortodoxă, 2012.

17. $L M=$ PRUTEANU, Petru (ed.), Liturghierul Misionar, Chişinău 2019. 
18. LOIA = PRUTEANU, Petru, Liturghia Ortodoxă: istorie şi actualitate, București, Edit. Sophia, 2013.

19. MANDALA = MANDALÀ, Marco, La protesi della liturgia nel rito bizantino-greco, Grottaferrata, Scuola tipografica italo-orientale S. Nilo, 1935.

20. MerCer = MerCer, Samuel A. B., The Ethiopic Liturgy, Its Sources, Development, and Present Form, New York, 1915.

21. MERCIER = MERCIER, B.-Ch., La Liturgie de Saint Jacques. Édition critique du texte grec avec traduction latine, col. „Patrologia Orientalis", 26, Turnhout, Éditions Brepols, 1946.

22. MURETOV = MУPETOB, Сергей, „Чин проскомидии в греческой Церкви с XII до половины XIV века", і̂n Чтения в Обществе любителей духовного просвещения, Москва, 1894.

23. PARENTI $=$ PARENTI, Stefano, $L$ ' anafora di Crisostomo. Testo $e$ contesti, col. „Jerusalemer Theologisches Forum”, 36, Münster, Aschendorff Verlag, 2020.

24. $P E=$ HÄNGgI, Anton, PAHL, Irmgard, Prex eucharistica: textus e variis liturgiis antiquioribus selecti, Fribourg, Editions universitaires, 1968.

25. QARAMAH = QARAMAH, Mihail, K., „The Byzantine Prothesis. Hypothesis of the Eucharistic Consecration of the «Commemorative Particles»", în European Journal of Scrience and Theology, 16.4/2020, pp. 5-14.

26. SAHAROV = CAXAPOB, Афанасий, $O$ поминовении усопших по Уставу Православной Церкви [Despre pomenirile celor adormiţi conform Tipicului Bisericii Ortodoxe], Сатисъ, 1995.

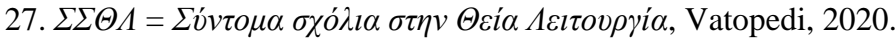

28. $T E X=$ MACARIE SIMONOPETRITUL, Triodul Explicat, trad. Ioan I. Ică jr., Sibiu, Edit. Deisis, 2008.

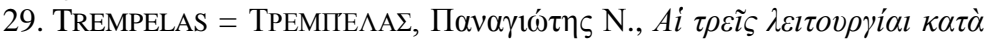

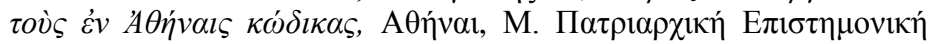
Елıтроли́, 1935.

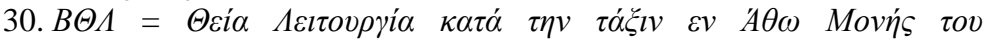

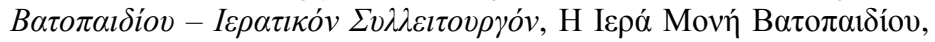
2020. 